\title{
THE DYNAMICS OF THE DEMOBILIZATION OF THE PROTEST CAMPAIGN IN
}

\author{
ASSAM \\ Tijen Demirel-Pegg \\ Indiana University-Purdue University Indianapolis
}

\begin{abstract}
This study highlights the role that critical events play in the demobilization of protest campaigns. Social movement scholars suggest that protest campaigns demobilize as a consequence of polarization within the campaign or the cooptation of the campaign leaders. I offer critical events as an alternative causal mechanism and argue that protest campaigns in ethnically divided societies are particularly combustible as they have the potential to trigger unintended or unorchestrated communal violence. When such violence occurs, elite strategies change, mass support declines and the campaign demobilizes. An empirical investigation of the dynamics of the demobilization phase of the anti-foreigner protest campaign in Assam, India between 1979 and 1985 confirms this argument. A single group analysis is conducted to compare the dynamics of the campaign before and after the communal violence by using time series event data collected from The Indian Express, a national newspaper. The study has wider implications for the literature on collective action as it illuminates the dynamic and complex nature of protest campaigns.
\end{abstract}

\section{International Interactions}

This is the author's manuscript of the article to be published in final edited form at:

Demirel-Pegg, Tijen (2016), "The Dynamics of the Demobilization of the Protest Campaign in Assam," International Interactions. http://www.tandfonline.com/doi/full/10.1080/03050629.2016.1128430 


\section{Introduction}

The year 2014 was marked by intense protests against the police after the killings of Michael Brown in Ferguson and Eric Garner in New York and the subsequent failure to indict the police officers that killed them. While large scale protests were held across the United States, an unexpected event happened: two police officers were shot to death in New York on December 20, 2014 by a man who was allegedly outraged by the Brown and Garner cases. The momentum for the Black Lives Matter movement in New York City was derailed as the police killings generated a backlash effect against demonstrators by critics and local leaders who maintained that it was not appropriate to keep protesting given the horrific nature of the police killings. Meanwhile, the New York police blamed the protesters for those killings. These events show that in the midst of a mobilization process, protesters can withdraw from the streets when unexpected events occur, and external pressure encourages them to stop demonstrating.

This study highlights the role that critical events play in the demobilization of protest campaigns. In the context of an ongoing protest campaign, critical events may alter protesters' tactics and their willingness to continue demonstrating, leading to the demobilization of the campaign. Typically, social movement scholars argue that protest campaigns demobilize as a consequence of a polarization between radical and moderate protesters or the cooptation of the campaign leaders. I offer critical events as an alternative causal mechanism and argue that protest campaigns in ethnically divided societies are particularly combustible as they have the 
potential to trigger unintended communal violence. ${ }^{1}$ When such violence occurs, elite strategies change, mass support declines and campaigns demobilize.

The connection between critical events and the demobilization of a campaign has remained largely under-theorized mainly because scholars have typically associated critical events with increased protest activity (Meyer and Staggenborg 1996, Rasler 1996). For instance, Rasler (1996) shows that the burning down of the Abadan cinema resulting in 400 deaths was one of the important critical events that escalated the protests during the Iranian revolution. Similarly, Lohmann (1994) argues that President Gorbachev's visit to East Germany in October 1989 where he publicly urged East German leaders to implement reforms was seen as a signal that the Soviet military forces would not intervene if people started protesting. In both cases, critical events are seen as having an escalatory effect on mass protests against the regime. Nonetheless, critical events can also have a de-escalatory effect. According to Staggenborg (1993:320), critical events are significant turning points that, whether intentional or not, alter expectations and perceptions of threats and opportunities, affecting the outcomes of protest campaigns. This definition allows for the possibility that critical events can lead to the demobilization of a protest campaign. For instance, the 1990/91 Gulf War was responsible for the demobilization of the First Intifada protest campaign. Until the Gulf War, Palestinian leaders

${ }^{1}$ Communal violence refers to an intense, sudden, though not necessarily wholly unplanned, lethal attack by civilian members of one ethnic group on civilian members of another ethnic group, with the victims chosen because of their group membership (Horowitz 2001:1). The intention to kill and the civilian nature of the perpetrators and the victims are the defining characteristics of communal violence. 
used nonviolent tactics to convey their message to the international community, knowing that Israel's military response would evoke international criticism. The onset of the Gulf War, however, shifted international attention away from the campaign, and created an opportunity for the Israelis to clamp down on the Palestinian activists by imposing a total curfew, limiting the Intifada's activities significantly (Alimi 2009:228-29).

To investigate how critical events can demobilize a protest campaign, I conduct a quantitative analysis of a single case study, the anti-foreigner protest campaign in the northeast Indian state of Assam between 1979 and 1985. The critical event in the Assam protest campaign proved to be the unexpected rise of communal violence in February 1983. By using original and fine-grained data collected from The Indian Express, a daily newspaper, I demonstrate that the 1983 communal violence played a major role in the demobilization of the campaign in this ethnically divided state. Though the communal violence was neither planned nor directed by the protesters, it had a significant impact on the campaign by compelling the campaign leaders to suspend protests temporarily, and leading to the withdrawal of one of the main ethnic groups that originally supported the campaign. Consequently, protests declined dramatically, never reaching the levels they did during the first four years of the campaign.

This study makes several important contributions to the theoretical literature. First, it examines the link between critical events and the demobilization process of a protest campaign. Second, this research expands our understanding of how protest campaigns demobilize. So far, scholars have mostly identified the use of violence or the creation of formal organizations as the main determinants of demobilization (Chenoweth and Stephan 2011, Nepstad 2011, Piven and Cloward 1977, Tarrow 1989). This study identifies communal violence in ethnically divided societies as another causal explanation. In societies where multiple ethnic groups compete for 
power, communal violence that occurs during a protest campaign, yet is not directed by the campaign leaders, is likely to lead to demobilization. Communal violence pushes protest leaders to change strategies and results in the withdrawal of and rank and file support. Third, this research brings a more nuanced understanding to the effects of violence on the demobilization of protest campaigns. Traditional studies of nonviolent resistance campaigns assume that opposition groups choose to pursue nonviolent strategies and strictly adhere to such tactics even when faced with severe repression. If they fail to maintain nonviolent discipline, then the campaign is more likely to fail to achieve its political goal as protesters leave the streets in the face of violence. In short, the use of nonviolent tactics is an important factor that avoids the premature demobilization of the campaign before groups gain important concessions from the government (Chenoweth and Stephan 2011, Nepstad 2011, Schock 2013, Schock 2005, Sharp 1973). On the other hand, social movement scholars who have studied the dynamics of protest campaigns note that radical groups frequently use violence, and this development allows the state to distinguish the radicals from the moderates. By making concessions to the moderates, state leaders are able to demobilize the protest campaign by coopting the moderates while isolating the radicals (della Porta and Tarrow 1986, Tilly 1978). Both of these strands of research assume that violence is a tactical choice designed to achieve political goals. ${ }^{2}$ Yet, I argue that violence is not

\footnotetext{
${ }^{2}$ My understanding of protest campaign is similar to that of social movement scholars in that it involves both types of actions: nonviolent ones as well as low level forms of violence, short of organized military operations. While demonstrations, boycotts, or strikes are nonviolent tactics typically used during protest campaigns, the potential for a violent outbreak exists as people might throw stones, break windows, or set vehicles on fire.
} 
necessarily strategic, and when it is unorchestrated in the context of a protest campaign, it can produce a shock that may demobilize a protest campaign, as happened in Assam. Thus, the aim of this study is to examine protest campaigns and improve our understanding of their dynamics in terms of how and when the scale and scope of protest actions escalates or de-escalates.

Theoretical Foundations: The Demobilization of Protest Campaigns and Critical Events Scholars who have studied protest campaigns frequently suffer from two limitations. First, scholars have mostly focused on the factors that predict success and have only included failed nonviolent campaigns as negative cases to identify the conditions for the achievement of the campaign's stated goals (Chenoweth and Stephan 2011, Nepstad 2011, Schock 2005). This approach tends to overlook dynamics that are unique to unsuccessful outcomes. Second, scholars of protest campaigns usually pay more attention to the origins and spread of mobilization rather than the demobilization process (Koopmans 1997, McAdam 1983, Tarrow 1998, Tilly 1978). Although demobilization is a crucial process that occurs within the trajectory of protest campaigns, it has attracted surprisingly little theoretical attention. ${ }^{3}$ Of the few scholars

\footnotetext{
${ }^{3}$ Demobilization refers to the process by which protesting decreases in scale and scope and eventually ends (Tilly and Tarrow 2007). While demobilization typically evokes an unsuccessful outcome, these two concepts are distinct. Although the demobilization of a nonviolent campaign often leads to its failure, demobilization might also precede a successful outcome. For example, the demobilization of the Baltic and Crimean Tatar protests in 1987 and 1988 under coercive measures eventually led to a successful outcome as they triggered other protests, ending with the fall of the Soviet Union (Beissinger 2002).
} 
that do study demobilization, the focus is on the cooptation or polarization processes. For instance, Piven and Cloward (1977) argue that the development of formally structured organizations greatly increases the prospects for elite influence and the cooptation of campaign leaders, thus, diminishing the campaign's disruptive potential. Others such as Tarrow (1989) and della Porta and Tarrow (1986) maintain that demobilization is the inevitable outcome of the expansion of a protest campaign and is largely driven by the polarization between moderates and radicals.

I advance a causal mechanism for demobilization that is different from either cooptation or polarization. I suggest that protest campaigns can demobilize because of critical events that constrain the leadership's protest strategies. Critical events are important turning points that affect public and elite attention to campaigns (Staggenborg 1993:320).

Scholars have examined critical events in different contexts in political science. For instance, several International Relations scholars have studied the impact of critical events, or shocks in the de-escalation or termination of strategic rivalries (Goertz and Diehl 1995, Rasler,Thompson and Ganguly 2013). While critical events are not sufficient to terminate or deescalate rivalries, they can contribute to a process of de-escalation of rivalries when political leaders take advantage of the uncertainty caused by the disruption of routine expectations (Rasler, et al. 2013:13-19). Scholars of Historical Institutionalism also have sought to understand institutional change via critical junctures (Collier and Collier 2002, Mahoney 2001, Polanyi 1957). Critical junctures relax structural influences (economic, cultural, organizational, and ideological) on political action significantly for a short period of time, widening the options available to political actors. The consequences of powerful actors' decisions during critical junctures typically have long term consequences (Capoccia and Kelemen 2007). Both strands of 
research, however, mostly emphasize the relaxation of structural constraints and the widening of political options, rather than structural changes that narrow the options available to political actors.

While studies of protest campaigns have examined the escalatory impact of critical events (Rasler 1996, Shawki 2012), with the notable exception of Staggenborg (1993), few scholars have provided theoretical guidelines as to how to identify critical events. Staggenborg suggests six types of critical events based on the extent of control the actors exert: large-scale socioeconomic and political events, natural disasters and epidemics, accidents, critical encounters, strategic initiatives, and policy outcomes (Staggenborg 1993:322). Large-scale socioeconomic and political events such as wars and depressions; natural disasters and epidemics; and industrial or nuclear accidents are critical events which neither campaign actors nor their opponents exert much control over. In contrast, strategic initiatives and policy outcomes are orchestrated by the campaign actors or their opponents. In strategic initiatives, campaign actors or the counter-campaign create events designed to mobilize support. Policy outcomes are official state responses to mobilization. States might adopt favorable or unfavorable policies that affect levels of support for campaigns.

Critical encounters, which the communal violence in Assam falls into, are events that involve face-to-face interactions or physical contact between authorities or other actors who are somewhat associated with the campaign. Such events occur when other social actors attempt to assert control using methods ranging from ridicule to violence, causing a sudden change in the trajectory of the campaign (Staggenborg 1993:327-28). Staggenborg argues that the level of control in critical encounters ranges from full control by the state or campaign leaders to little or no control. Thus, critical encounters might include events that occur during the campaign with 
the full knowledge and sanctioning of the elites or campaign leaders as well as events that are unauthorized or not approved by them. The shootings of the two police officers in New York during the Black Lives Matter campaign in the United States, for instance, happened within the context of the campaign but were not sanctioned by the elites or the campaign leaders. Similarly, in Assam, the killings of the mostly Muslim peasants by Assamese villagers during the protest campaign were critical encounters that were beyond the campaign leadership's control. While the campaign leaders had called for a boycott of the 1983 State Assembly elections that increased violence associated with protests in major towns, the violent attacks in rural areas were not controlled by the leaders of the Assam protest campaign (Kimura 2013:7). Therefore, the communal violence in Assam is distinct from the protest campaign in the sense that neither the protesters nor the campaign or the state leadership planned it. Nonetheless, the communal violence occurred in rural areas when ethnic tension was significantly elevated in the region.

\section{The Causal Mechanism}

In societies where communal divisions are salient, opposition leaders broaden the base of resistance to include members of different ethnic groups. Nonetheless, the inclusion of different ethnic groups makes the unity of the campaign precarious particularly if campaign activities highlight ethnic cleavages (Horowitz 2001, Svensson and Lindgren 2011). Mass actions can exacerbate tensions by provoking fear or anger between different communal groups. When an ethnic group demonstrates strength by protesting in large numbers, others feel threatened especially if the protesters' claims have ethnic overtones. In such instances, protest campaigns become highly combustible, increasing the chances of communal violence. For instance, Uzbek demonstrations over ethnic claims to land and housing led to communal violence in Kyrgyzstan 
in 1990. Similarly, the Azeri protests against Armenian demands for the unification of Karabakh with Armenia triggered communal violence, resulting in mass killings of Armenians (Horowitz 2001, Varshney 2002).

Although communal violence occurs outside the control of the protest leadership, it can dramatically affect the trajectory of the campaign. Opposition elites face pressure to shut down the campaign to prevent more ethnic violence. Moreover, protesters that are members of the ethnic groups targeted during the violence withdraw their support from the campaign as a result of the increased prominence of ethnic allegiances. The leaders also face the challenge of finding ways to reinvigorate enthusiasm and maintain solidarity particularly when political elites or the media call for a slowdown to give the communities time to heal. Even if the campaign resumes, the loss of momentum leads to a decline in protest activity and lower levels of support. A striking example is the collapse of the civil disobedience campaign in India as a result of HinduMuslim violence in the early 1920s. As the British were fighting against the Ottoman sultan during World War I, the Muslims in India turned against the British, providing Gandhi the opportunity to unite Hindus and Muslims in a civil disobedience campaign for the freedom of India. Even though Muslim-Hindu unity was created for some time, in mid-1921, Muslim clerics in Malabar in the state of Kerala started to protest against the British treatment of the caliph in Turkey. These protests first turned into a violent rebellion against the British, and then degenerated into Hindu-Muslim violence (Varshney 2002:142), creating a Hindu-Muslim divide within the Indian national movement across the country. Gandhi and the Congress Party were unable to maintain the campaign as communal divisions became too obvious. Consequently, Gandhi ended the campaign in 1922 and the Congress Party withdrew from mass mobilization until 1929 (Varshney 2002:134-35). 
Communal violence leading to the demobilization of a protest campaign differs from previously identified causal pathways in the literature. For Piven and Cloward (1977) and Tarrow (1989), the broadening of the support base leaves campaigns vulnerable to internal divisions, resulting in a withdrawal of support, and finally, demobilization. However, the factors that trigger the withdrawal of public support are different. According to Piven and Cloward (1977), the expansion of the protest campaign prompts the government to coopt the opposition to channel their disruptive behavior into organized forms of contention. Yet, campaign leaders usually overestimate their ability to keep the campaign strong and effective via organizations while simultaneously underestimating the amount of resources needed to maintain an organization. As leaders get isolated from the protesters, disruptive behavior declines, leaving the remaining agitated protesters discouraged and vulnerable to repression.

Alternatively, Tarrow (1989) highlights the competitive dynamics among groups and its potential to lead to internal divisions before governments can coopt campaign leaders. When protest campaigns first emerge, disruptive protests diffuse to different locations and segments of the society. Competition for mass support intensifies as both established groups, such as trade unions or political parties, and new groups join the campaign. Nonetheless, the early enthusiasm for protesting wanes over time and the personal costs of participation wear people down. The decline in participation further encourages competition for mass support. While moderates lead the shift toward conventional forms of collective action such as strikes and demonstrations, smaller and newer groups turn radical as they employ violent tactics to distinguish themselves from the moderates. Similar to Piven and Cloward's (1977) cooptation model, the state represses the radicals selectively while accommodating the moderates, reinforcing the polarization between these groups. Faced with repression, the radicals resort to more violent tactics, resulting 
in a further withdrawal of public support. The split between the moderates and the radicals eventually leads to the demise of the protest campaign (Tarrow 1989).

The causal mechanism I offer, however, allows for a disruption of the trajectory of protests by an unexpected and unorchestrated event. As Figure 1 illustrates, if a critical event such as communal violence occurs in an ethnically divided society, the campaign leadership refrains from employing strategies that might exacerbate ethnic tensions. Governing elites usually assert their authority and criticize campaign leaders for mobilizing ethnic political demands and bringing ethnic issues to the forefront. In addition, political elites often pressure campaign leaders to suspend their activities in a highly tense ethnic and political environment to prevent the outbreak of more violence. As Horowitz (2001:286) suggests, ethnic groups can be provoked more easily to engage in large scale violence during mass demonstrations or processions, particularly if the core issues closely relate to ethnic demands. Given the elevated tension as well as the political elite's pressure in the aftermath of communal violence, campaign leaders will typically avoid organizing protests.

Furthermore, as communal violence highlights the divisions within the society, ethnic groups, particularly those that have been victimized by the violence, withdraw their support from the protest campaign as it becomes more difficult to act collectively across ethnic lines. When the protest campaign secures the support of different ethnic, religious, and/or socioeconomic groups, protest leaders face challenges in keeping these different groups together after a major shock like communal violence. If one of the groups included in this broad coalition has affiliations to the group that has been targeted, campaign solidarity declines. The group affiliated to the victims questions the purpose of the campaign and pressures the leaders to modify campaign policies that undermine the interests of the targeted groups. Other groups also make 
demands to strengthen their profile, further undermining the campaign's broad coalition. Thus, the ability of the leaders to organize mass events decreases. Furthermore, the leaders spend more time and energy into finding ways to re-energize the campaign and rebuild solidarity.

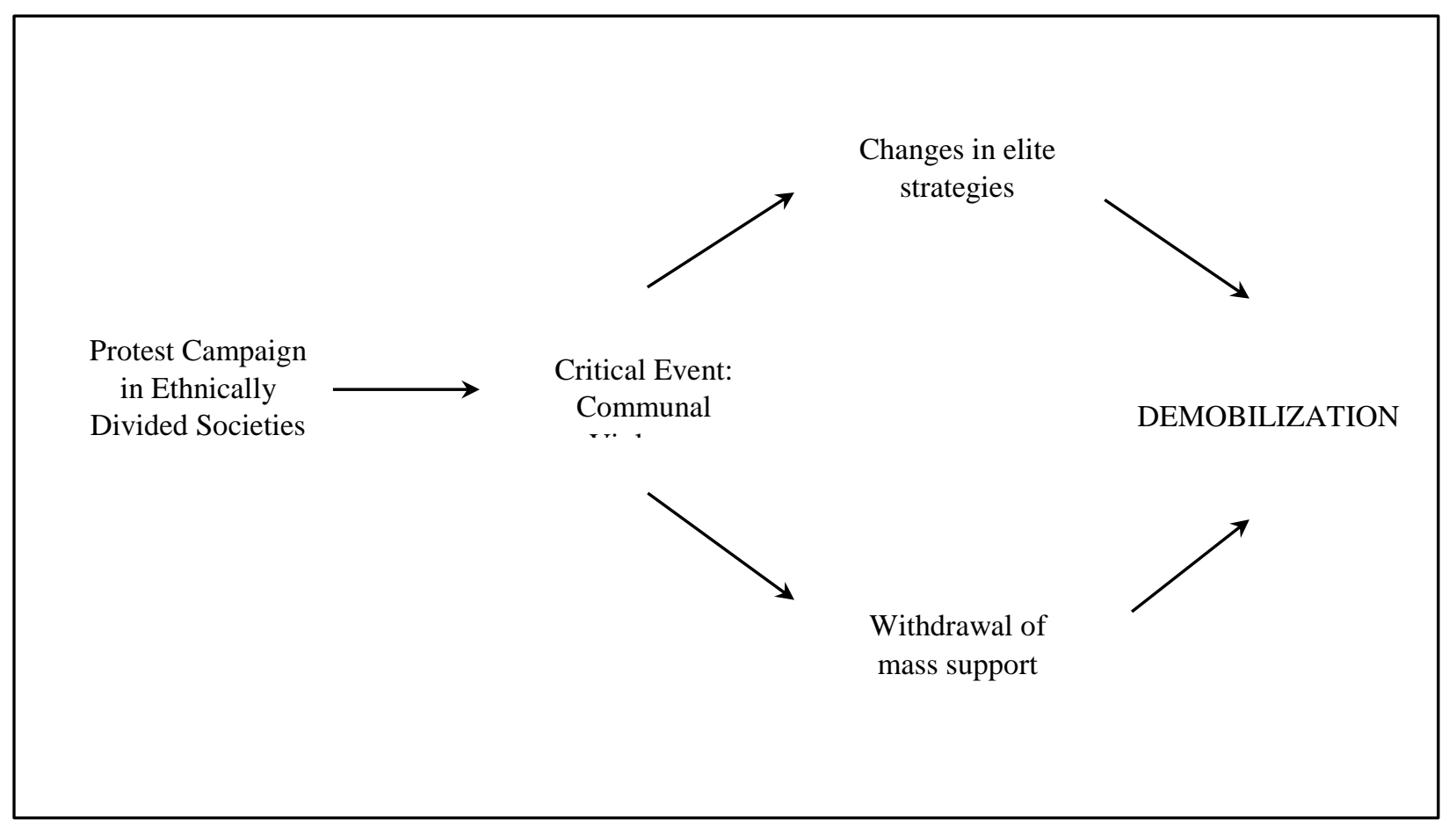

FIGURE 1 Causal Pathway for the Demobilization of a Protest Campaign

\section{Assam and the Anti-Foreigner Protest Campaign, 1979-1985}

Assam is an ethnically heterogeneous society which has also witnessed large scale immigration from many parts of the subcontinent (particularly East Bengal) over the last hundred years (Baruah 1986). According to the 1971 census records (before the anti-foreigner protest campaign started in 1979) $72.5 \%$ of the population in Assam was Hindu, 24.6\% was Muslim, and $2.61 \%$ was Christian. The Muslim population in Assam includes ethnic Assamese and 
Muslims of Bengali descent while Hindus also include ethnic Assamese and Hindu Bengalis that immigrated to Assam. People are divided along linguistic lines, which, simultaneously also stands for the division between "indigenous" and "immigrant" groups. As of 1971, approximately $68 \%$ of the population in Assam spoke languages or dialects that are considered to be of "indigenous" people while $29 \%$ of the population spoke "immigrant" languages or dialects (Baruah 1986:1188).

The protest campaign in Assam emerged to drive out both Hindu and Muslim immigrants (Kimura 2013). Threatened by rapid population growth following a large influx of Muslim immigrants from Bangladesh and concerned by the growing political power of the middle-class mostly Hindu Bengali immigrants, ethnic Assamese started a state-wide protest campaign in 1979 to pressure the Indian Government to identify illegal immigrants, delete their names from voting lists, and deport them to Bangladesh. The campaign was led by the All Assam Students Union (AASU) and the All Assam Gana Sangram Parishad (AAGSP), an umbrella organization formed in 1979 to direct the protest activities against illegal immigrants (Baruah 1999). While the campaign leaders demanded the deportation of all those who entered after 1951, the Indian state felt a humanitarian commitment toward the Hindu refugees who crossed into India from East Pakistan to escape the atrocities of the Pakistani state before it became Bangladesh in 1971. Therefore, the Indian Government insisted that 1971 should be the baseline year, allowing foreigners who entered before that year to stay (Kimura 2013).

The campaign gained mass support among ethnic Assamese, including indigenous Muslims who had settled in Assam before colonization. The leaders of the campaign made a deliberate attempt to frame the immigration issue along secular lines by highlighting the illegality of it rather than identifying certain ethnic immigrants, especially the Muslims, as the 
unwanted population (Baruah 1986, Kimura 2013). Thousands of students, government employees, peasants and workers participated in demonstrations, strikes, and sit-ins throughout the first four years. The government responded with a mix of repression and accommodation as it used force against the protesters at times while also periodically negotiating with the campaign leaders. In early 1983, the campaign intensified in the wake of the state legislative assembly elections scheduled for February. The central government insisted on using the electoral rolls of 1979 without deleting the names of foreigners while the campaign leaders strongly opposed and called for an electoral boycott. Both nonviolent and violent protests intensified before the elections as many Assamese citizens supported the boycott. In addition to the strikes aimed at preventing election preparations and the filing of nominations, the AASU and the AAGSP organized a general strike that was supported by state employees. As clashes between the police and the protesters increased, the Assam government brought in additional police from other states. In the midst of this tense political environment, communal violence occurred when Assamese and Tiwa (an indigenous minority group) peasants in the rural areas attacked mostly Muslims of Bengali descent (Kimura 2013). The first large-scale ethnic violence took place in the Darrang District on the northern bank of the Brahmaputra River on February 11. One week later, about 1,600 to 2,000 Muslims of East Bengali origin were killed in several villages around Nellie in the Nagaon District (Kimura 2013:68). According to Kimura (2013), the Nellie 
incident was one of the largest incidents of ethnic violence in India's rural areas since India gained its independence in $1947 .^{4}$

After the communal violence, the AASU and AAGSP suspended the campaign for a few months, resuming protest activities in August 1983. Yet, protest activity remained at dramatically lower levels after the ethnic violence of 1983. As a result of extensive negotiations, the campaign leaders and the Indian Government signed the Assam Accord in August 1985, both agreeing to disenfranchise all the foreigners that entered Assam between 1966 and 1971 for ten years and deporting those that came after 1971 (Baruah 1999). Figure 2 illustrates the trajectory of the protest campaign and the occurrence of communal violence in Assam in $1983 .{ }^{5}$

${ }^{4}$ Smaller scale communal violence in 1980 in Assam is not considered as a critical event as it did not change the overall trajectory of the protest campaign. See Capoccia and Kelemen (2007) for a discussion of identification of critical events.

${ }^{5}$ This figure is generated by using the count of events. 


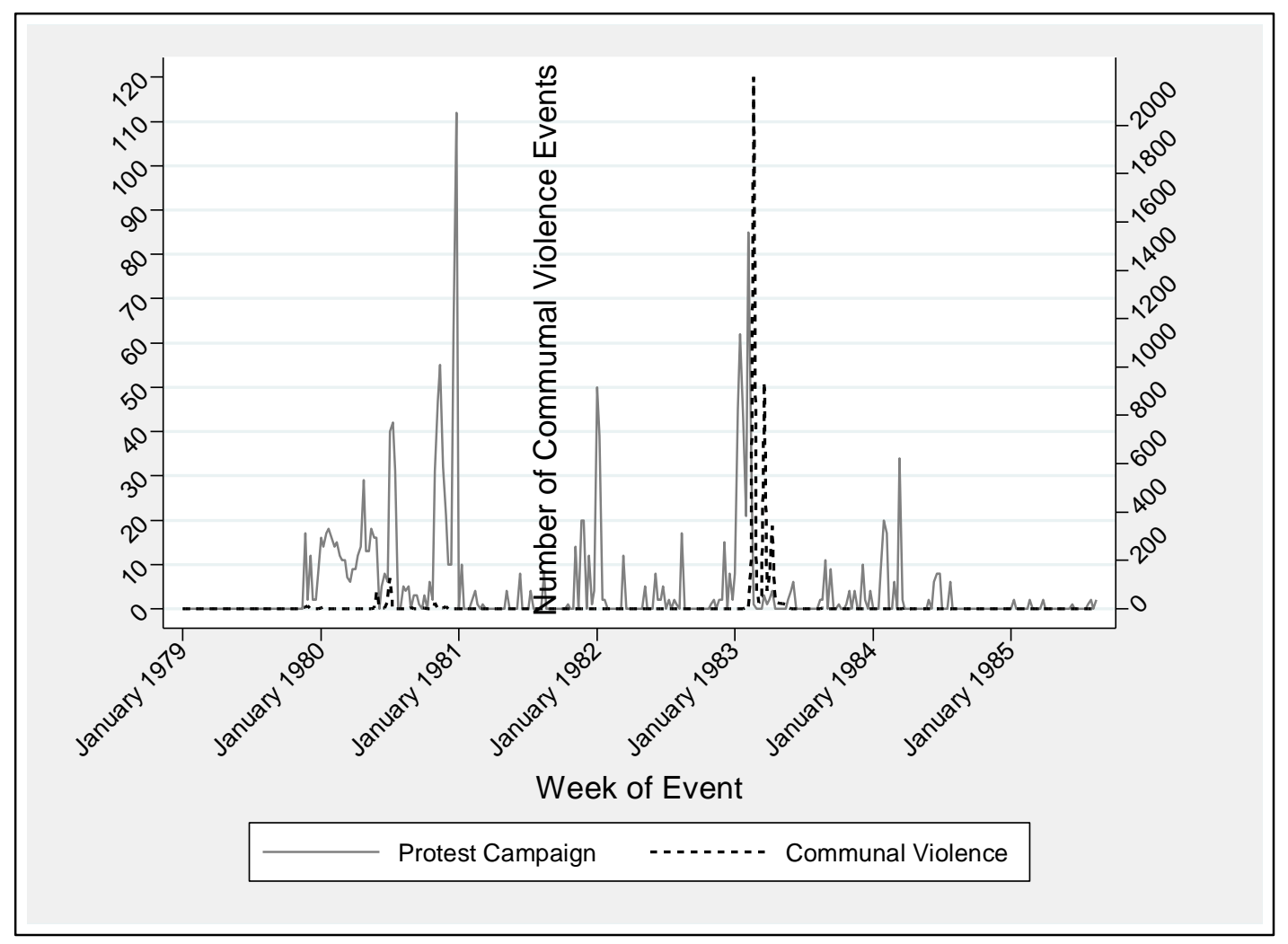

FIGURE 2 Weekly Protest Activity Before and After Communal Violence in Assam

\section{Assam as a "Least Likely" Case}

Assam is an ideal case to examine the effects of communal violence on a protest campaign because it is a "least likely" case, meaning that it is harder to prove the argument as opposed to a case that easily fits the argument (George and Bennett 2005). First and foremost, communal violence took place in the spring of 1983, but the campaign ended in August 1985, more than two years later. In most other instances, communal violence ends protest campaigns rather abruptly, as in the case of the Tamil protests against the declaration of Sinhalese as the sole official language in Sri Lanka in 1958 (DeVotta 2004). In Assam, though, protests actually resumed a few months after communal violence and continued intermittently for two more years. Therefore, demonstrating the demobilizing effects of communal violence is more challenging in 
the Assam case. Moreover, the campaign in Assam was well-established since 1979, long before the ethnic violence took place. Protests were organized regularly and were usually well attended. A strong campaign like the one in Assam should be less vulnerable to the negative effects of communal violence than other more ad hoc campaigns like the one in Nigeria after the reelection of Goodluck Jonathan in 2011. Therefore, a demonstration of the decline in protest activity as a result of communal violence in Assam should provide strong support for the demobilizing effect of ethnic violence in the context of ongoing protest campaigns.

\section{Research Design}

\section{Data $^{6}$}

The analysis is based on data collected from The Indian Express, a national daily newspaper, from January 1, 1979 to August 16, 1985. The data set covers both nonviolent and violent forms of protest action such as demonstrations, strikes and clashes with the police, as well as incidents of communal violence. ${ }^{7}$ Events were coded for the date, actor, location, target, number of participants, number of injured and number of deaths. ${ }^{8}$ The state's repressive and accommodative actions were also coded for the same time period. Events that lacked information on the exact date, actor, and type of action were omitted from the data set. In total,

\footnotetext{
${ }^{6}$ The codebook used for this data set is posted in the Appendix.

${ }^{7}$ Ethnic violence is distinguishable from protest violence as communal violence occurred in rural areas whereas protest activity typically took place in major cities. Ambiguous cases were excluded.

${ }^{8}$ Ambiguous events were excluded.
} 
8,488 events $^{9}$ were hand coded by the author ${ }^{10}$ based on a list of events compiled mostly from Krain (2000) and Moore and Lindstrom's (1996) Violent International Conflict Data Project (VICD) and weighted by a scale that is based on Krain's (2000) scale for opposition and state actions ranging from 1 to $25 .{ }^{11}$ A detailed explanation of the weighting scheme and its modification of Krain's scale can be found in the Appendix. The data were then aggregated in weekly intervals.

The underrepresentation of the frequency of the actual events, the overreporting of violent events and the selective reporting of events are three obvious issues that could potentially challenge the validity of the data as a consequence of coding from a single newspaper. In terms of underrepresentation, The Indian Express had correspondents based in Assam throughout the protest campaign directly reporting from the area and providing detailed information regarding a wide range of collective actions, thus reducing the chance of underrepresentation. Moreover, the data illustrate similar trends to those found by scholars who have studied the anti-foreigner protest campaign and communal violence in Assam (Baruah 1999, Kimura 2013), somewhat minimizing concerns over validity. Regarding the issue of overreporting violence and underreporting nonviolence (Day,Pinckney and Chenoweth 2015), I used secondary sources

\footnotetext{
${ }^{9}$ Every action of every actor was coded separately. For instance, if students shouted slogans and threw stones, two separate actions were coded. Clashes are coded for both protesters and the police.

${ }^{10}$ Since only one coder was involved, potential issues of inter-coder reliability do not arise.

11 The correlation coefficients for all variables between the number of events and the weighted data range from .87 to .98 .
} 
(Baruah 1986, Baruah 1999, Kimura 2013) to check the accuracy of the reporting whenever possible. Nonetheless, given the media attention on Assam and the protesters after the mass killings, underreporting of nonviolence seems unlikely. Finally, selective reporting of events might introduce bias to the data because reporters do not (and cannot) report every single collective action that occurs in the public domain. Therefore, they are left to make decisions regarding what to report and how much detail to present. The concern is that newspapers report events that are likely to attract more attention and underreport minor events, thus, disregarding the vast majority of contentious activity (McCarthy,McPhail and Smith 1996). Nonetheless, others have argued that selective reporting is an issue when and where protests occur frequently. In locations like Assam in the late 1970s, when protests were less frequent, they are more newsworthy and receive greater coverage (Earl,Martin,McCarthy and Soule 2004:71). Moreover, the longitudinal design of the study reduces potential challenges to the internal validity of the analyses since selective reporting would be an issue both before and after the communal violence.

\section{Model and Estimation}

To understand the effect of communal violence on protest activity, I conduct a single group time series analysis that is commonly used in epidemiology, which compares a preintervention time series with a post-intervention time series (Linden and Adams 2011). Accordingly, I model communal violence as an "intervention" on the protest activity series, the dependent variable, to examine two types of changes in protest activity: the immediate change in protest activity right after the first occurrences of communal violence and the long term change in the trajectory of protest activity until the end of the campaign. 
Protest activity, the dependent variable, is the total weekly score of nonviolent and violent forms of collective action including demonstrations, strikes, boycotts, and arson. The minimum values of protest typically reflect the weeks when protesters use few nonviolent tactics; while the maximum values reflect the weeks when protesters resort to nonviolent tactics more frequently and/or resort to violent tactics such as clashing with the police. Hence, the demobilization phase represents the period before the end of the campaign when the values of the dependent variable are declining, indicating that protesters used both nonviolent and violent forms of tactics less frequently.

To assess the changes of the communal violence on protest activity, I construct a time variable denoting the number of weeks from the start of the campaign until its end. The coefficient of this variable represents the trajectory of protest activity until the communal violence begins. The intervention variable is a dummy variable coded 1 for the weeks the communal violence are on (weeks 7 to 12 in 1983) and 0 otherwise. The coefficient of intervention is the intercept at the time when communal violence occurs and indicates any immediate changes in protest activity right after the communal violence. Finally, a postintervention time variable is constructed to denote the number of weeks after the communal violence. The coefficient of this variable represents the change in the slope of protest activity. If the communal violence indeed has a demobilizing effect, then the coefficients of either intervention or post-intervention time, or both should be negative and have significant $p$ values. A significant negative coefficient for intervention would signify a sudden drop in protest activity and a significant, negative slope after intervention would suggest a decay, which could be steep or gradual, depending on the slope. 
I also control for state actions as both repression and accommodation have the potential to affect protest activity. While several studies have shown that repression increases protest activity by creating a backfire effect (Chenoweth and Stephan 2011, Francisco 1995, Rasler 1996), others have found that carefully targeted and consistent repression is likely to demobilize protesters (Beissinger 2002, Tarrow 1989). Repression is the total weekly score of repressive actions carried out by the lower level authorities, typically the police, directly confronting the protesters, such as blocking the roads; as well as those sanctioned by higher level authorities including the imposition of curfews or restrictions on civil liberties.

Similarly, the state's accommodative tactics can have a positive or negative effect on protests. Accommodation can increase protest activity as it signals weakness (Rasler 1996); or it can lead to a decline in protests as it creates splits between the moderates and the radicals (Tarrow 1989) or coopts the protesters (Piven and Cloward 1977). Accommodation is measured as the total weekly score of state concessions that include actions like negotiations, removing restrictive laws and regulations, or withdrawing the army from the region. ${ }^{12}$

I estimate both a Zero-Inflated Negative Binomial Regression (ZINB) and a Poisson autoregressive (PAR) model of order (p) to examine the effects of communal violence on the protest campaign. Both ZINB and PAR are count models that are appropriate for the nature of the dependent variable in this analysis. A ZINB analysis is appropriate for count models that are overdispersed $^{13}$ and have a high number of zero observations of the dependent variable (Long

\footnotetext{
${ }^{12}$ Descriptive statistics for the variables can be found in the Appendix.

13 The variance of protest activity is greater than its mean, indicating overdispersion.
} 
1997). ${ }^{14}$ The data are also ordered in time, meaning that past values influence future values. ${ }^{15}$ As Brandt et al (2000) show, estimating event counts that are time dependent with a standard count model might lead to inefficient estimates. The systematic dynamics of the data have to be taken into account while working with time series event count data such as the series on the Assam protest campaign, which a PAR analysis is able to do. The PAR model is suitable for cyclical and short-memoried processes that are mean reverting (Brandt and Williams 2001). As Figure 2 demonstrates, the protest activity series has a cyclical pattern as the peaks in the series are followed by declines. The plot for the Autocorrelation Function (ACF) of the series (Figure 3) shows autocorrelation only in the first four lags indicating that the process has a short-term memory. Therefore, I use the PAR model developed by Brandt and Williams (2001) to account for the time-series nature of the data and a ZINB to deal with the high frequency of zero observations.

\footnotetext{
${ }^{14}$ Vuong test statistics indicate that ZINB is preferable to a regular negative binomial.

${ }^{15}$ A transfer function model assessing the impact of intervention on a time series is not suitable as the data are based on event counts (Brandt and Williams 2001).
} 


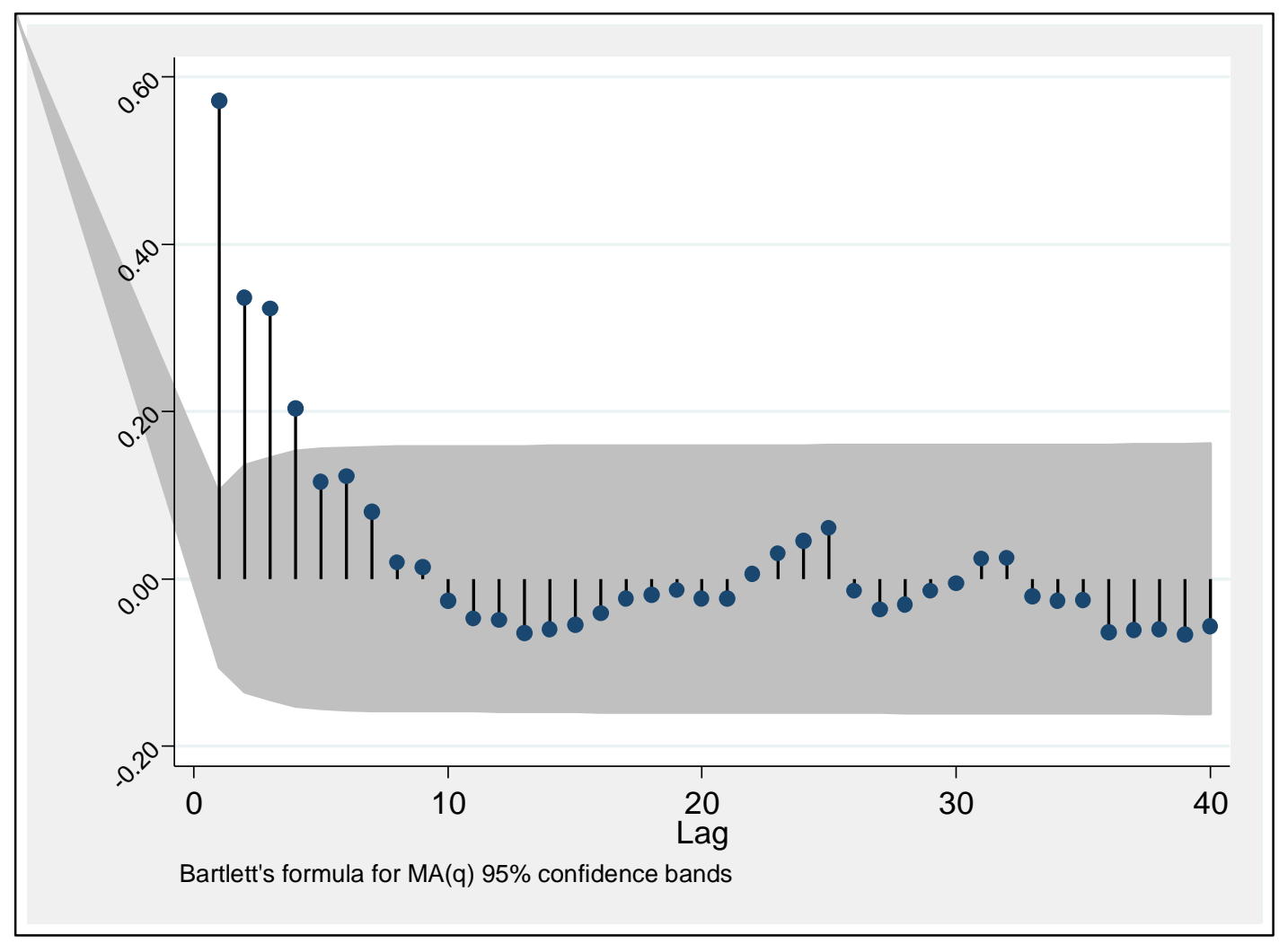

FIGURE 3 Autocorrelation Function Plot for Protest Activity

\section{Findings}

Table 1 shows the results of the ZINB and PAR $(2)^{16}$ analyses for the protest activity in Assam between January 1979 and August $1985 .{ }^{17}$ The Critical Event Model with the single

16 The AR parameters in larger lags were insignificant.

${ }^{17}$ The same analyses were conducted on the unweighted data and the results are similar. Also, the Critical Event Model was run on nonviolent and violent protest activity separately. Overall, the results still confirm the findings of the Critical Event Model. The short-term positive impact of communal violence on violent protests can perhaps be explained due to the radicals' initial 
group analysis controlling for repression and accommodation suggests that protest activity decreased significantly when communal violence began in the middle of February 1983 . Both intervention and post intervention are statistically significant $(\mathrm{p}<.001$ and $\mathrm{p}<.05$ respectively) in the ZINB analysis. The PAR results are also similar as both variables significantly decrease protest activity, indicating that protest activity declined immediately after communal violence began and continued to decline in its aftermath.

TABLE 1 ZINB and PAR Estimates of Protest Activity in Assam

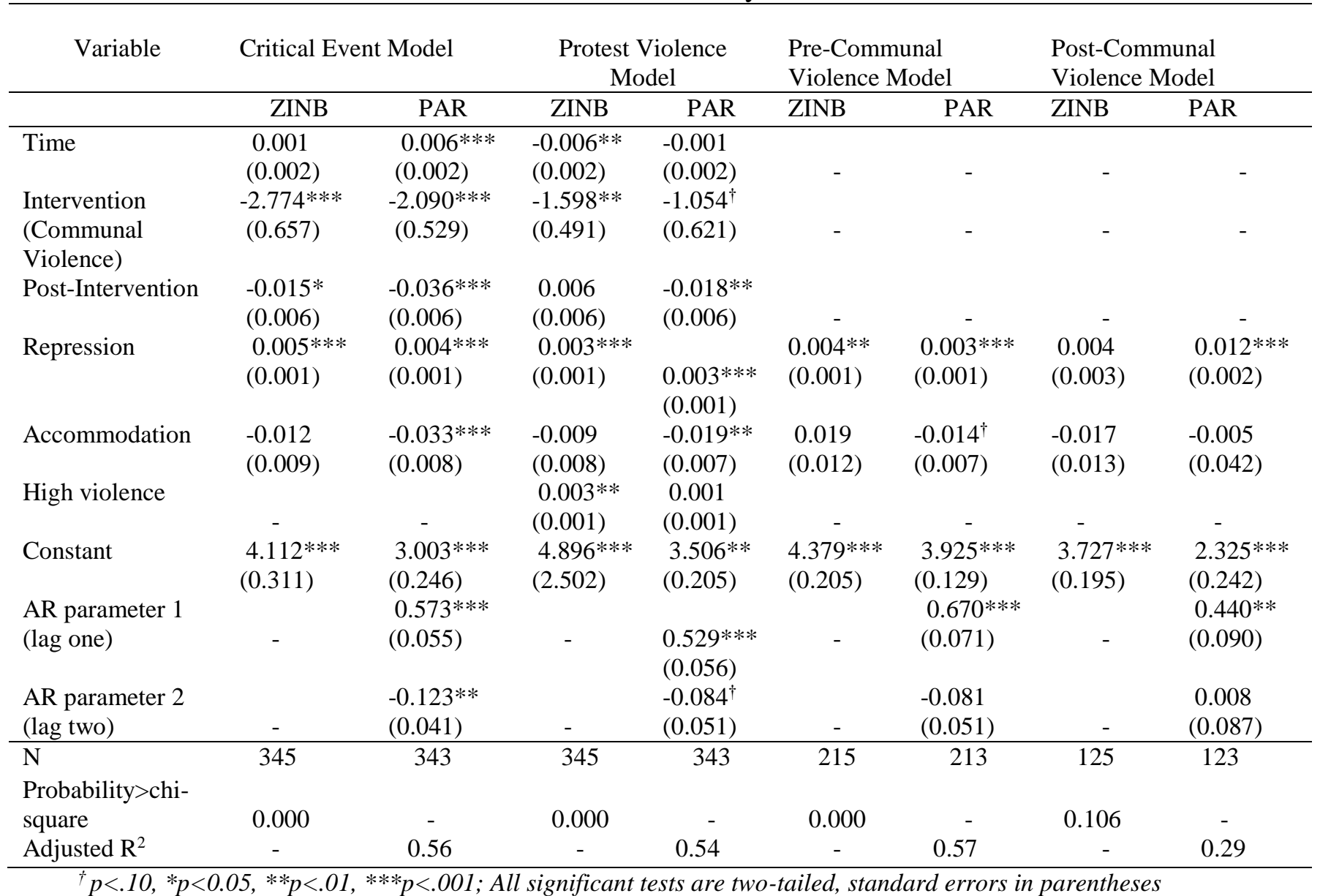

desire to show their continued determination to carry on. The results of robustness checks can be found in the Appendix. 
These findings confirm that the communal violence led to a sudden drop in protest activity and continued to stifle the campaign until the Assam Accord was signed in August 1985. Table 2 illustrates the factor changes in the rate of protest activity for a clear interpretation of the coefficients. Accordingly, protest activity decreases by a factor of 0.06 after the communal violence begins, and continues to decline by a factor of 0.99 after the communal violence is over.

TABLE 2 Factor Change in Expected Rate of Protest Activity ${ }^{\mathbf{1 8}}$

\begin{tabular}{lcccc} 
& $\begin{array}{c}\text { Critical Event } \\
\text { Model }\end{array}$ & $\begin{array}{c}\text { Protest } \\
\text { Violence Model }\end{array}$ & $\begin{array}{c}\text { Pre-Communal } \\
\text { Violence Model }\end{array}$ & $\begin{array}{c}\text { Post-Communal } \\
\text { Violence Model }\end{array}$ \\
\hline Time & - & -0.99 & & \\
\hline $\begin{array}{l}\text { Intervention (Communal } \\
\text { Violence) }\end{array}$ & -0.06 & -0.20 & - & - \\
\hline $\begin{array}{l}\text { Post-Intervention } \\
\text { Repression }\end{array}$ & -0.99 & - & - & - \\
\hline Accommodation & 1.01 & 1.00 & 1.00 & - \\
\hline High Violence & - & - & 0.98 & - \\
\hline
\end{tabular}

The Critical Event Model also shows that repression leads to an increase in protest activity in both the ZINB and PAR analyses suggesting the existence of a backfire effect (Chenoweth and Stephan 2011, Francisco 1995, Rasler 1996). This effect is relatively strong, as repression increases protest activity by a factor of 1.01 , holding other variables constant (Table 2). This finding is particularly interesting because it suggests that the campaign continued to demobilize despite the backfire effect of repression. Accommodation has a significant and

${ }^{18}$ Only the expected rates of significant coefficients are listed 
negative effect only in the PAR analysis. The negative impact of accommodation indicates that, independent of communal violence, accommodative actions might have contributed to the demobilization of the protest campaign, confirming Piven and Cloward's cooptation model or Tarrow's polarization model. To understand the effects of accommodation and repression more precisely, I examine the impact of these variables on protest activity during the pre- and postintervention phases in Models 3 and 4 respectively.

In the Protest Violence Model, I control for high levels of protest violence as previous studies have shown that heavy protest violence leads to the demobilization of a campaign as participation declines when violence erupts and polarization between the radicals and the moderates occurs (Chenoweth and Stephan 2011, della Porta and Tarrow 1986, Tarrow 1989). ${ }^{19}$ For this model only, I construct a new dependent variable for protests that does not include heavy violence and create a new control variable, high violence representing acts such as abductions, armed attacks, and clashes with security forces that occur during the protest

\footnotetext{
${ }^{19}$ Although studies have demonstrated that elections are associated with high levels of violence (Dunning 2011), elections did not have a significant impact on protest activity. Parliamentary elections in December 1979 and the State Assembly elections in February 1983 were the only two elections held in Assam during the time period under study. The 1984 parliamentary elections were postponed and held in December 1985. A dummy variable coded 1 for three months before and after each election was statistically insignificant in the ZINB estimates of the Critical Event Model.
} 
campaign. ${ }^{20}$ The results of the ZINB and PAR analyses suggest that high violence is significant, but in the opposite direction. High violence does not seem to deter protests in Assam, and instead, increases it by a factor of 1.00 (Table 2). Thus, the Protest Violence Model shows that high levels of violence during the elections was not the cause of the demobilization of the campaign. The heavy violence in Assam was primarily associated with the protesters' election boycott as anti-election groups, mostly ethnic Assamese, tried to intimidate pro-election groups (mostly Bengalis) from participating (Baruah 1999, Kimura 2013).

The Pre- and Post-Communal Violence models examine the effects of state actions before and after communal violence respectively to understand if state policies had differential effects across the two time periods. For instance, Indian leaders could have been more inclined to make concessions to the protesters after ethnic violence began to alleviate the tension in the region. Alternatively, the leaders might have resorted to more repressive measures in order to crush the protesters and bring order to Assam. Both ZINB and PAR analyses show that repression has a positive and significant effect on protest activity during the pre- and postcommunal violence periods, suggesting that the effect of repression remained relatively consistent across the protest campaign. Accommodation has no significant effect in the pre and post-intervention period, indicating that the negotiations between the Indian government and the campaign leaders, and the attempts to coopt the opposition did not demobilize the campaign. As Figure 1 also shows, protest activity had already declined dramatically when the parties agreed to participate in the last round of negotiations, which started in April 1985, almost two years after

${ }^{20}$ The full range of events are listed under the High Intensity Collective Action category in the Codebook posted in the Appendix. 
the ethnic killings took place. Thus, neither model suggests that sate actions led to the decline in protest activity.

Predictive margins generated based on the ZINB analysis of the Critical Event Model provide a more nuanced understanding of the effect of the communal violence on protest activity (Figure 4). The predicted number of weekly protest events declines steadily over the course of time. As Figure 4 illustrates, the predicted number of protest events is 60 immediately after the communal violence. About six months later, however, the number of protest events goes down to 40 , and in about a year, the number is below 30, indicating a more than $50 \%$ decrease in protest activity. In approximately two years after the communal violence, the predicted number of protest events further declines to slightly above ten a week. When these numbers are put into context, the first year in particular seems quite significant. One year after the communal violence, none of the issues the protesters were campaigning on had been resolved and the leaders of the campaign were still trying to mobilize support. So, a more than $50 \%$ decline in the first year suggests that the communal violence had a significant effect on the demobilization of the campaign. 


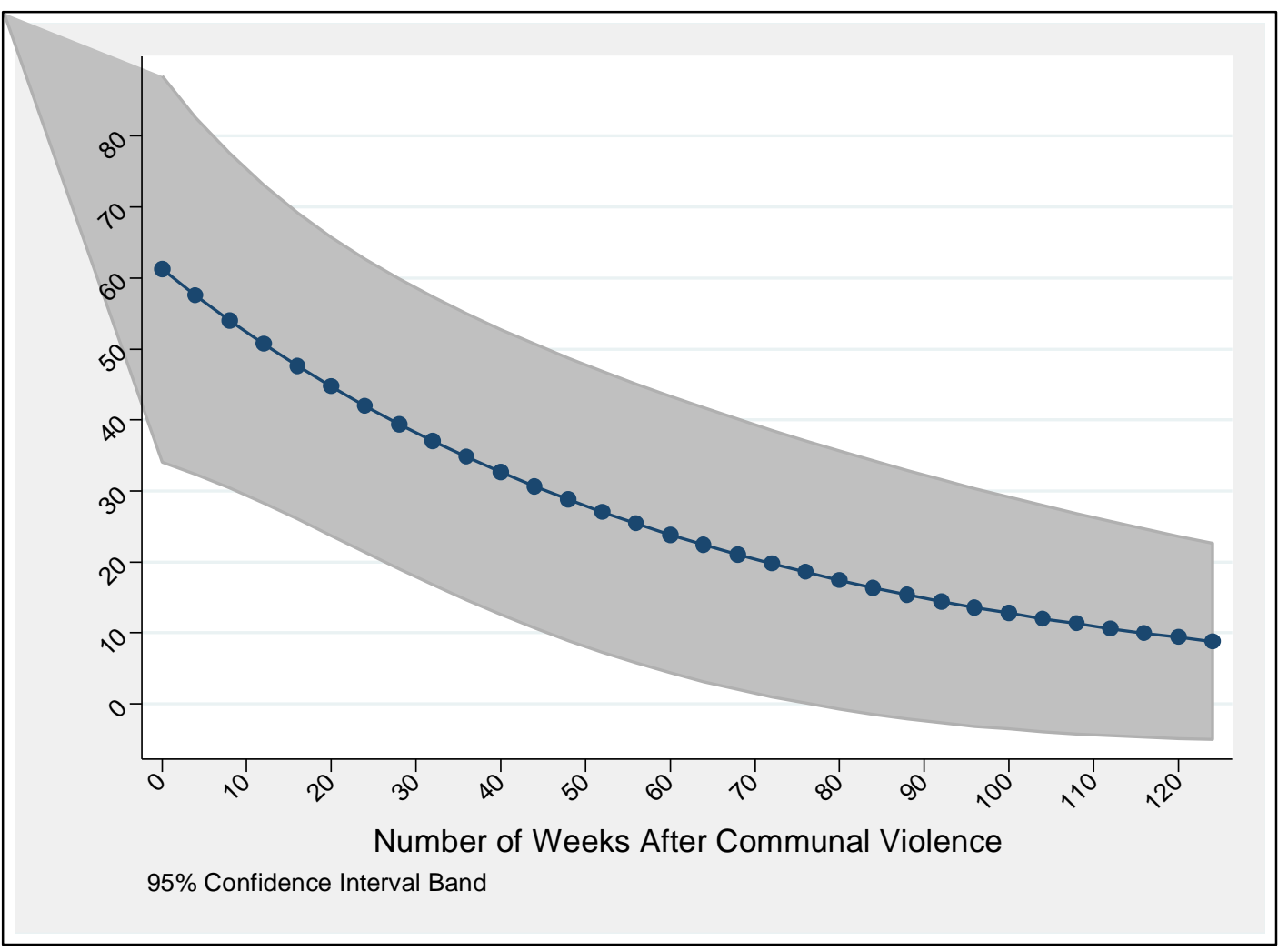

FIGURE 4 Predicted number of Events after the Communal Violence

To evaluate the predictive power of the Critical Event Model, I generated out-of-sample forecasting, which is an ideal tool for cross-validation. The main idea is to compare the predicted values generated by the model to the observed values. ${ }^{21}$ Moreover, these forecasts can be easily compared to those of other models. Since polarization did not occur in the Assam case, forecasts on a polarization model (Tarrow 1989) cannot be tested. ${ }^{22}$ However, because the

${ }^{21}$ Generating predicted values of observations that are not included in any of the analyses is another option for cross validation.

${ }^{22}$ The United Liberation Front of Assam (ULFA), a separatist insurgent group, was established in 1979 but did not actively challenge the state until the late 1980s. 
Indian government used accommodative tactics to coopt the protesters, I am able to generate outof-sample forecasts based on a Cooptation Model that has the accommodation variable only (Piven and Cloward 1977) and compare them to the out-of-sample forecasts of the Critical Event Model.

To obtain the out-of-sample forecasts, I first run ZINB regressions to estimate the parameters for both models by holding back the weeks after the communal violence ends. ${ }^{23}$ Based on these estimates, I then generate out-of-sample probabilities of protest activity for the period after the critical event and calculate Theil's $U$ to evaluate the predictive power of each model. Theil's $\mathrm{U}$ is a ratio where the numerator is the sum of squared prediction errors and the denominator is the sum of squared prediction error from a naïve model, which expects no change from one observation to the other (Farnum and Stanton 1989:26). Values below one indicate a better performance of the statistical model compared to the naïve model.

The plots in Figure 4 illustrate the number of observed protest events and the out-ofsample predictions based on the Critical Event and the Cooptation Models after the intervention. Even though neither one of the models predict protest activity very accurately, the Critical Event Model performs much better than the Cooptation Model. ${ }^{24}$ The Theil's U statistics for the Critical Event and the Cooptation Models are 0.99 and 3.36 respectively, indicating that although neither greatly outperforms the naïve model, the Critical Event Model is still a better predictor of

${ }^{23}$ I hold back the weeks after June 1983, approximately $33 \%$ of the observations, after the communal violence. These estimates can be found in the Appendix.

${ }^{24}$ The AIC scores for the Critical Event and Cooptation models are 1427.15 and 1535.25 respectively. 
protest activity during the demobilization period. As Figure 4 shows, the Cooptation Model predicts higher values of protest activity while the Critical Event Model predicts no activity during the demobilization period. ${ }^{25}$

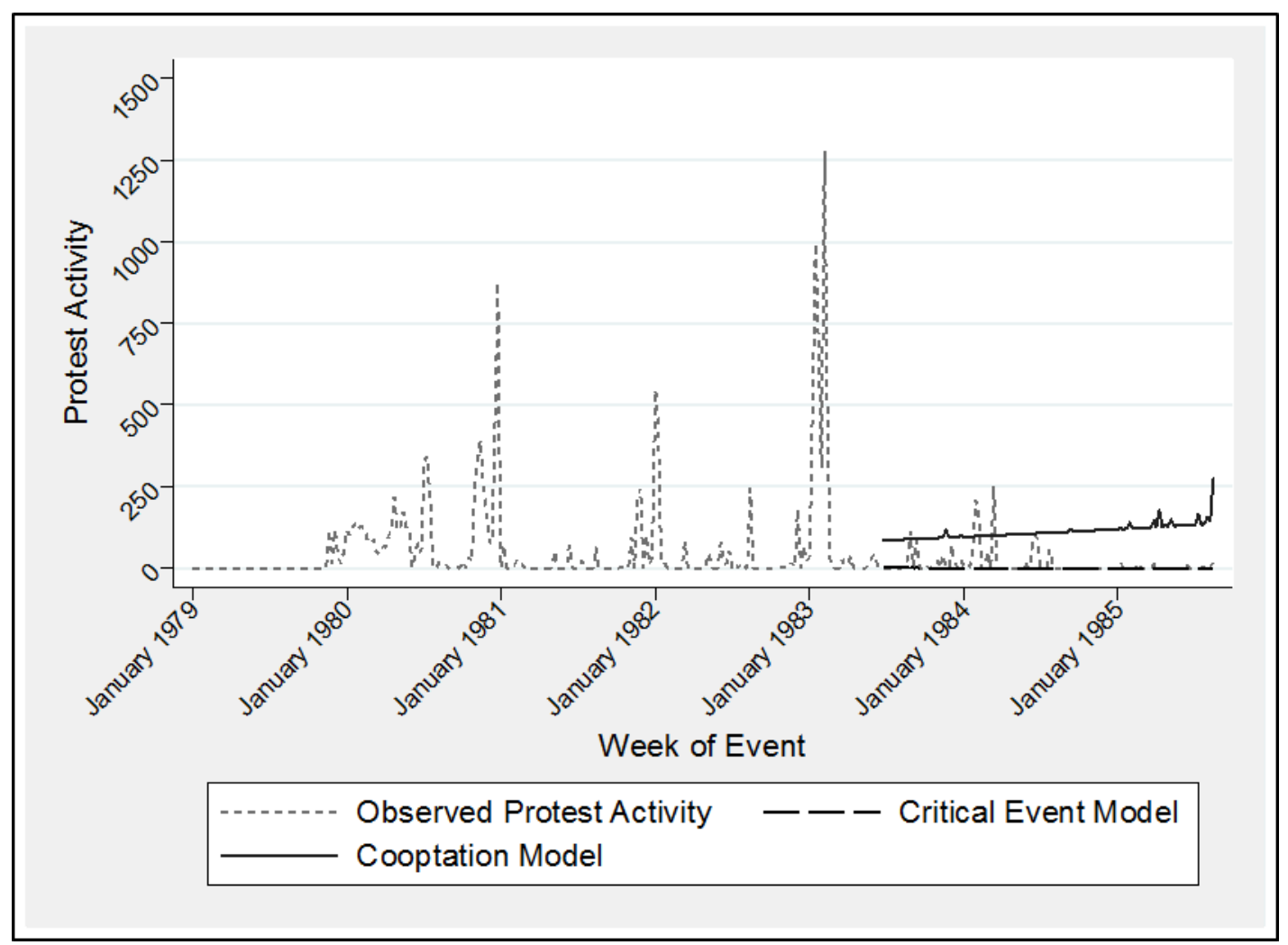

FIGURE 5 Out-of-sample Forecasts for the Critical Event and Cooptation Models

Overall, the empirical analyses show that the communal violence in February 1983 led to the demobilization of the protest campaign. Until the communal violence, the campaign was

\footnotetext{
${ }^{25}$ The Critical Event plot suggests that the variables present in the model are not sensitive enough to protest activity occurrence to be able to detect those spikes. This might be due to the inability of the model to account for the autoregressive component of the series.
} 
strong and had most of the characteristics identified by scholars of nonviolent resistance as likely to lead to a successful outcome. First, the campaign started off by employing nonviolent tactics and secured substantive mass support from ethnic Assamese as well as from non-immigrant Muslims, the most important factor for pressuring the government to change its unfavorable policies according to Chenoweth and Stephan (2011). The campaign leaders mobilized thousands of people, including students, teachers, peasants, state government officials and oil workers and brought them out into the streets. For instance, in November 1979, nearly two million people Assam participated in the civil disobedience campaign (Baruah 1999). Second, the high level of participation allowed for tactical innovation throughout the first four years, increasing the campaign's resilience in the face of state repression (Chenoweth and Stephan 2011, McAdam 1983, Schock 2005). For instance, in late December 1979, shortly after launching a civil disobedience campaign, the protesters imposed an economic blockade, stopping the transportation of crude oil, plywood, and jute from Assam to the rest of the country (Indian Express, December 30, 1979). Moreover, many state police and government officials supported the campaign against illegal immigrants, dramatically reducing the level of repression used against the protesters (Kimura 2013). According to Nepstad (2011) and Chenoweth and Stephan (2011), such loyalty shifts are crucial for the success of a campaign. Finally, potentially more radical supporters of the campaign did not have a violent insurgent group to turn to (Chenoweth and Stephan 2011), keeping the mass support for the campaign relatively intact. In short, the protest campaign in Assam featured several mechanisms that should have enabled the leaders to continue to mobilize people and put pressure on the government before communal violence began. 
So, how exactly did the communal violence set the demobilization process of the campaign in motion? Communal violence turned into a critical event that significantly limited the campaign leader's available strategies. After the extent of the violence became known, members of the Indian central government repeatedly called for peace and calm in the region (The Indian Express, February 22 \& March 15, 1983) while political actors and civil society groups offered competing explanations for the occurrence of such brutal violence. The campaign leaders blamed the Indian Government for imposing the elections without changing the electoral rolls (Kimura 2013) whereas several members of the government accused the protesters of inciting violence in the region. For instance, right after the most publicized mass killings in Nellie on February 18, Prime Minister Indira Gandhi publicly blamed the protest leaders for the violence in Assam (The Indian Express, February 22, 1983). The campaign leadership was also criticized for their failure to condemn violence immediately after the communal violence started (Gandhi 1983). When the temporary suspension of the campaign was finally announced in late March, the leaders emphasized the need to focus on relief, rehabilitation, and integration (The Indian Express, March 28, 1983). Even though protests resumed in August 1983, the intensity of the campaign decreased dramatically (Figure 2).

The communal violence further entrenched ethnic divisions within the society alienating ethnic Assamese and immigrant Muslims (Gupta 1983). The tension among these two groups had important consequences for the campaign. After the extensive killings of Muslim peasants, many Muslim protesters withdrew their support, including those who had settled before colonization and, hence, were seen as indigenous. For instance, one of the top Muslim student leaders resigned from his position after the occurrence of communal violence (Kimura 2013). Consequently, the campaign leaders had to devote considerable time and resources into 
addressing internal divisions. Several Muslim members of the AASU issued an ultimatum to the AASU leadership demanding a correction in what they perceived as a pro-Hindu communal tilt (Baruah 1999). Similarly, several other indigenous groups, such as the Bodos, began to make demands that emphasized their distinctiveness from ethnic Assamese. In January and December 1984, the AASU organized two separate national conventions to address the rifts among such groups by emphasizing the urgent need to provide a unified political platform (Baruah 1999). While the lack of primary sources makes it impossible to pinpoint which of these two causal mechanisms (the leaders backing off versus withdrawal of support) is more important, the secondary sources clearly demonstrate the role of communal violence in the demobilization process.

Two significant concessions by the central government in New Delhi led to the end of the protest campaign. First, in 1984, the Election Commission of India decided that the electoral rolls in Assam were to be revised based on the 1971 electoral rolls, which meant that the immigrants who entered after 1971 would be disenfranchised (The Indian Express, July 13, 1984). The campaign leaders saw the Election Commission's decision as a confidence building measure as many illegal immigrants who settled in Assam after the creation of Bangladesh in 1971 would be disenfranchised. Second, the Indian government left the state government out of the negotiations, recognizing the power of the campaign leaders, who insisted that the current government was not elected by the people of Assam in 1983 as many ethnic Assamese boycotted the elections (Baruah 1999). Therefore, they argued, the state government was illegitimate and should not participate in any discussions (Narayan 1985).

In early 1985, the lack of enthusiasm for continued protests was already evident. Many Assamese defied the campaign leaders' call to boycott the Republic Day celebrations in early 
1985 by joining them in the main stadium in Guwahati (The Indian Express, May 8, 1985). The final round of negotiations between the campaign leaders and the central government began in April 1985, and the Assam Accord was eventually signed on August 15, 1985. Accordingly, all foreigners who had entered between 1966 and 1971 would be disenfranchised for ten years and those who had entered after 1971 would be deported. The current state government would be dissolved and new elections would be held in December 1985 based on the new electoral rolls (The Indian Express, August 16, 1985).

\section{Conclusion}

This empirical analysis of the dynamics of the demobilization of the protest campaign in Assam has several implications for the study of nonviolent campaigns. First, it offers an alternative causal mechanism for the demobilization of a protest campaign by demonstrating that critical events can trigger demobilization. Communal violence in ethnically divided societies can curtail mass support for the protest campaign and force campaign leaders to suspend protest activities. While scholars have often highlighted the escalatory effects of critical events, this analysis shows that they can also be important turning points in the demobilization of a protest campaign.

Second, this study suggests that the participation of large numbers of people and the inclusion of various sectors and groups do not always set off mechanisms that lead to success. Even if repression triggers a backfire effect and motivates larger number of people to participate, campaigns can still demobilize. Indeed, similar to Piven and Cloward's (1977) and Tarrow's (1989) models, the Assam case shows that broadening the support base makes coalition maintenance challenging in ethnically divided societies. When communal violence against 
Muslim immigrants occurred in Assam, Muslim protesters withdrew their support, forcing the campaign leadership temporarily to shift their strategy from confronting political authorities to trying to unify the different groups within the campaign.

Third, the Assam case shows that violent protest activity does not necessarily undermine the strength of a protest campaign as scholars of nonviolent resistance maintain. Although protesters resorted to violent tactics, mobilization levels remained high throughout the first four years of the campaign. Instead, a critical event, communal violence, eventually led to the demobilization of the protest campaign. In line with Davenport and Moore's (2012) call for better mapping and understanding of diverse forms of political conflict and violence, this study indicates that various types of violence can have differential effects on protest dynamics.

From a policy standpoint, the implications of the Assam campaign for states and activists are quite alarming. In ethnically divided societies, protests that highlight ethnic differences can have unintended violent consequences and lead to deeper societal cleavages in the long term. States should be aware of this potential and calculate the costs of repressing and fueling protests by taking into account the possibility of large-scale communal violence. Likewise, protesters should develop strategies to prevent the escalation of ethnic tension as it can have detrimental effects on the campaign.

At a more general level, the Assam case illustrates the unpredictable nature of protest dynamics. Scholars of political contention have long recognized the challenges associated with identifying causal pathways due to the unpredictability of contentious interactions between multiple actors. This study explains how an unpredictable event can demobilize a protest campaign. Although this study has limitations in its generalizability across different campaigns due to the unique communal patterns and protest dynamics in Assam, it highlights an alternative 
causal path to demobilization and, thus, brings scholars one step closer to understanding the complex dynamics of contentious politics. 
References

Alimi, Eitan Y. (2009) Mobilizing under the Gun: Theorizing Political Opportunity Structure in a Highly Repressive Setting. Mobilization 14(2):219-37.

Baruah, Sanjib. (1986) Immigration, Ethnic Conflict, and Political Turmoil--Assam, 1979-1985. Asian Survey 26(11):1184-206.

. (1999) India against Itself : Assam and the Politics of Nationality. Critical Histories.

Philadelphia: University of Pennsylvania Press.

Beissinger, Mark R. (2002) Nationalist Mobilization and the Collapse of the Soviet State. Cambridge: Cambridge University Press.

Brandt, Patrick T., and John T. Williams. (2001) A Linear Poisson Autoregressive Model: The Poisson Ar(P) Model. Political Analysis 9(2):164-84.

Brandt, Patrick T., John T. Williams, Benjamin A. Fordham, and Brian Pollins. (2000) Dynamic Modeling for Persistent Event Count Time Series. American Journal of Political Science 44(4):823-43.

Capoccia, Giovanni, and R. Daniel Kelemen. (2007) The Study of Critical Junctures: Theory, Narrative, and Counterfactuals in Historical Institutionalism. World Politics 59(3):34169.

Chenoweth, Erica, and Maria J. Stephan. (2011) Why Civil Resistance Works : The Strategic Logic of Nonviolent Conflict. New York: Columbia University Press.

Collier, Ruth Berins, and David Collier. (2002) Shaping the Political Arena: Critical Junctures, the Labor Movement, and Regime Dynamics in Latin America. Notre Dame, Ind. :: University of Notre Dame Press.

Davenport, Christian, and Will H. Moore. (2012) The Arab Spring, Winter, and Back Again? (Re)Introducing the Dissent-Repression Nexus with a Twist. International Interactions 38(5):704-13.

Day, Joel, Jonathan Pinckney, and Erica Chenoweth. (2015) Collecting Data on Nonviolent Action: Lessons Learnd and Ways Forward. Journal of Peace Research 52(1):129-33.

della Porta, Donatella, and Sidney Tarrow. (1986) Unwanted Children: Political Violence and the Cycle of Protest in Italy: 1966-1973. European Journal of Political Research 14.

DeVotta, Neil. (2004) Blowback: Linguistic Nationalism, Institutional Decay, and Ethnic Conflict in Sri Lanka. Stanford: Stanford University Press.

Dunning, Thad. (2011) Fighting and Voting: Violent Conflict and Electoral Politics. The Journal of Conflict Resolution 55(3):327-39.

Earl, Jennifer, Andrew Martin, John D. McCarthy, and Sarah A. Soule. (2004) The Use of Newspaper Data in the Study of Collective Action. Annual Review of Sociology 3065-80.

Farnum, Nicholas.R., and LaVerne W. Stanton. (1989) Quantitative Forecasting Methods. PWSKent Pub.

Francisco, Ronald A. (1995) The Relationship between Coercion and Protest: An Empirical Evaluation in Three Coercive States. The Journal of Conflict Resolution 39(2):263-82.

Gandhi, Rajmohan. April 11. 1983, 1983 Assam: Some Questions and Answers. The Indian Express, 5.

George, Alexander L., and Andrew Bennett. (2005) Case Studies and Theory Development in the Social Sciences. Bcsia Studies in International Security. Cambridge, Mass.: MIT Press. 
Goertz, Gary, and Paul F. Diehl. (1995) The Initiation and Termination of Enduring Rivalries: The Impact of Political Shocks. American Journal of Political Science 39(1):30-52.

Gupta, Shekhar February 24, 1983 Assam Violence Has No Set Pattern. The Indian Express, 7. Horowitz, Donald L. (2001) The Deadly Ethnic Riot. Berkeley: University of California Press. Kimura, Makiko. (2013) The Nellie Massacre of 1983: Agency of Rioters. New Delhi: Sage Publications India.

Koopmans, Ruud. (1997) Dynamics of Repression and Mobilization: The German Extreme Right in the 1990s. Mobilization 2(2):149-65.

Krain, Matthew. (2000) Repression and Accommodation in Post-Revolutionary States. 1st ed. New York: St. Martin's Press.

Linden, Ariel, and John L. Adams. (2011) Applying a Propensity Score-Based Weighting Model to Interrupted Time Series Data: Improving Causal Inference in Programme Evaluation. Journal of Evaluation in Clinical Practice 17(6):1231-38.

Lohmann, Susanne. (1994) The Dynamics of Informational Cascades: The Monday Demonstrations in Leipzig, East German, 1989-91. World Politics 47(October):42-101.

Long, Scott. (1997) Regression Models for Categorical and Limited Dependent Variables. Thousand Oaks: Sage Publications.

Mahoney, James. (2001) The Legacies of Liberalism : Path Dependence and Political Regimes in Central America. Baltimore :: Johns Hopkins University Press.

McAdam, Doug. (1983) Tactical Innovation and the Pace of Insurgency. American Sociological Review 48(6):735-54.

McCarthy, John D., Clark McPhail, and Jackie Smith. (1996) Images of Protest: Dimensions of Selection Bias in Media Coverage of Washington Demonstrations, 1982 and 1991. American Sociological Review 61(3):478-99.

Meyer, David S., and Suzanne Staggenborg. (1996) Movements, Countermovements, and the Structure of Political Opportunity. American Journal of Sociology 101(6):1628-60.

Moore, Will H., and Ronny Lindstrom. (1996) The Violent Intranational Conflict Data Project (Vicdp) Codebook. Department of Political Science, University of California - Riverside.

Narayan, Hemendra. February 19, 1985 Show of Strength by Assam Agitation Leaders. Indian Express.

Nepstad, Sharon Erickson. (2011) Nonviolent Revolutions : Civil Resistance in the Late 20th Century. New York: Oxford University Press.

Piven, Frances Fox, and Richard A. Cloward. (1977) Poor People's Movements: Why They Suceed, How They Fail. New York: Pantheon Books.

Polanyi, Karl. (1957) The Great Tansformation. New York :: Rinehart.

Rasler, Karen. (1996) Concessions, Repression, and Political Protest in the Iranian Revolution. American Sociological Review 61(1):132-52.

Rasler, Karen A., William R. Thompson, and Sumit Ganguly. (2013) How Rivalries End. 1st ed. ed. Philadelphia :: University of Pennsylvania Press.

Schock, Kurt. (2013) The Practice and Study of Civil Resistance. Journal of Peace Research 50(3):277-90. . (2005) Unarmed Insurrections : People Power Movements in Nondemocracies. Minneapolis, MN: University of Minnesota Press.

Sharp, Gene. (1973) The Politics of Nonviolent Action. Boston, MA.: Porter Sargent. 
Shawki, Noha. (2012) The 2008 Food Crisis as a Critical Event for the Food Sovereignty and Food Justice Movements. International Journal of Sociology of Agriculture and Food 19(3):423-44.

Staggenborg, Suzanne. (1993) Critical Events and the Mobilization of the Pro-Choice Movement. Research in Political Sociology 6319-45.

Svensson, Isak, and Mathilda Lindgren. (2011) From Bombs to Banners? The Decline of Wars and the Rise of Unarmed Uprisings in East Asia. Security Dialogue 43(2):219-37.

Tarrow, Sidney G. (1989) Democracy and Disorder : Protest and Politics in Italy, 1965-1975. Oxford: Oxford University Press.

. (1998) Power in Movement : Social Movements and Contentious Politics. Cambridge Studies in Comparative Politics. 2nd ed. Cambridge, U.K. ; New York: Cambridge University Press.

Tilly, Charles. (1978) From Mobilization to Revolution. Reading, Mass.: Addison-Wesley Pub. Co.

Tilly, Charles, and Sidney G. Tarrow. (2007) Contentious Politics. Boulder, Colorado: Paradigm Publishers.

Varshney, Ashutosh. (2002) Ethnic Conflict and Civic Life : Hindus and Muslims in India. New Haven [Conn.]: Yale University Press. 


\section{APPENDIX \\ for \\ The Dynamics of the Demobilization of the Protest Campaign in Assam By Tijen Demirel-Pegg}

This appendix includes the following sections:

Section A: Explanation of the Coding Procedures and the Codebook used in the data collection

Section B: Descriptive Statistics

Section C: Robustness Checks 


\section{A. EXPLANATION OF CODING PROCEDURES AND THE CODEBOOK}

\section{Coding Procedures}

I followed multiple steps to construct the codebook and weight the data. First, I identified the four broad event categories that I needed data for: 1) state accommodation; 2) state repression; 3) group collective action; and 4) external support to the group. These categories were followed by the lists of actors involved in the Assamese protest campaign.

For state actions, I relied on a majority of Krain's (2000) list of repressive and accommodative events. ${ }^{26}$ Krain includes a variety of repressive state actions, ranging from seizing assets to use of torture, as well as a comprehensive list of accommodative actions ranging from increasing security of target group to incorporation into government. Even though these lists cover a wide range of events, I discovered some additional categories that were essential to my four cases throughout the coding process. Therefore, I added violent arrests of opposition leaders; halt negotiations; curfews; declaration of President's Rule or Governor's Rule; ${ }^{27}$ teargassing; violent disruption of group organization; beating up; clashes with group; damaging property; bombing; burning houses and bridges; and burning entire villages to the repressive events lists. These events came up with some frequency and provided detailed information about the exact form of events.

I then labeled the repressive events based on their objectives and decision making agencies. Preventive repression corresponds to repressive acts imposed by higher level authorities, such as the government or the judiciary, to demobilize the contenders and to prevent future acts of contention. The declaration of martial law, and the restriction of the right of assembly, for instance, fall into this category of repression. Reactionary repression, on the other hand, stands for repressive acts of lower level agents, such as the police, applied during the course of a contentious episode in an attempt to respond to collective action and maintain or reestablish order. Teargassing the protesters or damaging property are examples of reactionary repression. I consider arrests as a separate category because it is not always clear if arrests result from centralized policy directives, or if they are consequences of ad-hoc decisions made by the local police. Finally, I grouped all repressive events under six broader categories: Restrict; Seize; Warn; Judicial Actions; Non-Judicial Actions; and Use of Force.

Regarding the state's accommodative policies, I expanded Krain's list by adding organizing discussion meetings or committees, and withdrawal of army. The Indian state used these two types of policies during the protest waves and insurgencies as a form of accommodation. Again, I grouped similar types of events under broader categories: Negotiations; Judicial Accommodation; Non-Judicial Accommodation; and Group Recognition. For the purpose of systematic coding, I arbitrarily assigned the broad categories a 3-digit code and the specific event types a 4-digit code which started with the first two digits of the broader category. All repressive events that involve violence were assigned a 9 at the very end (thus, violent actions are all 5-digit codes ending with 9). All the codes for accommodative events start

\footnotetext{
${ }^{26}$ I did not include mass killings because some form of military armed attack, burning villages or bombing already covered this category.

27 Article 356 of the Constitution of India grants the President the right to dissolve or suspend a state legislature and place the state under direct federal rule if he is satisfied that there has been failure of the constitutional machinery in the state.
} 
with a 1 and the repressive ones start with a 2 . This code assignment was particularly helpful later throughout the data management process because it made it easier to identify similar types of events and their respective broader categories for aggregation purposes. It also helped me to detect miscoding, if any, more easily. The following are examples of categories of accommodation and repression with their respective codes.

For group actions, I used a majority of the Violent International Conflict Data Project (VICDP) events list (Moore and Lindstrom 1996). The VICDP is a data project, which has generated conflict and cooperation data at the sub-national level. Events from the Integrated Data for Event Analysis Framework (IDEA) (Bond,Bond,Oh,Jenkins and Taylor 2003) was also helpful in identifying specific events that were not included in the VICDP project, such as hijacking, and taking hostages. For the purpose of distinguishing between situations in which violence is or is not used, I added the "violent" versions of demonstrations, strikes and sit-ins to the list. I also created two separate categories for demonstrations based on size. Demonstrations with less than 200 participants are coded as small scale and the ones with more than 200 are coded as large scale. Even though the cut-off point of 200 participants is arbitrary, there is a pragmatic reason behind it. The Indian Express usually reports massive demonstrations as featuring "hundreds" or "thousands" of demonstrators. I am conservatively interpreting "hundreds" as at least 200, and therefore, using it as my cut-off point.

After completing the list for group actions, I grouped those under five broader categories: Accommodative Group Actions; Low Intensity Collective Action; Medium Intensity Collective Action; and High Intensity Collective Action. Again, the broader category was assigned a 3digit code and the specific events were assigned a 4-digit code. All the events that involved violence were assigned a 9 at the end. All collective action events start with a 5.

In addition to collective action I included a "Splits" category for groups to code information about group cohesion. The list of events in this category does not reflect a wide range of group characteristics because the scope of the study is not on organizational aspects of the groups. Instead, it includes the events that are the results of splits within a group. These specific events are disagreement between factions; forming an organization as a result of split; expelling members; armed attack against other factions; and militants surrendering. These events also have codes starting with a 5 because they are related to groups.

For the list of acts of external support to the group, I built on Heraclides' (1990:368-69) list of events which are specifically designed to fit cases with external involvement in secessionist conflicts. For example, some of the events in his list including providing access to communication, providing sanctuary and training, or giving direct military assistance such as armed intervention constituted the basis of the list for external support to the group. I also added firing across borders and granting asylum to leadership of group to the list to make it more comprehensive. All the events for external support to the group are arranged under two larger categories: Material and Diplomatic/Political Support. Material Support has three sub-categories based on the level of involvement: Low, Moderate and High. The 3 digit codes for these main categories start with an 8 and the specific events have 5 digit codes, just like the rest of the codebook.

While compiling the list of events for state, group, and external actor actions, I deliberately attempted to include similar policy options across the board. Obviously, the same exact policy options that are available to the state are not available for the group and vice versa. However, if the state has the option of putting down a demonstration, then demonstration is 
included among the list of group actions; and so is allowing demonstrations in state's own territory for external support actions.

Finally, for the list of actors and targets, I used the actor/target list in Moore and Lindstrom's (1996) VICDP as a starting point for my initial deliberations on what kind of actors to include. The specific party names and factions, names of governors, chief ministers, names of religious or ethnic groups along with broader categories of students, peasants, workers, and businessmen, for instance, are listed in the codebook. These specific actors were organized based on 7 types of actors and targets: State, Social Actors, Political Parties, Religious Groups / Populations, Insurgent Groups, State Enforcement, and External Actors. All the broader categories have 5 digit codes and the specific actors and targets have 6 digit codes. If there is more detailed information available, then those more specific ones have 7 digit codes. For example, in Assam, the code for the State is 33100, for the Governor 331011, and for Governor Shri T.S. Misra, it is 3310113.

Once the entire list of events was compiled, I assigned scores to each event to reflect the intensity of these events more realistically. It would simply not be accurate to assume that the state's restriction of assembly has the same impact as launching an armed attack. If both of these events would be assigned a score of 1 (or simply counted by frequency), it might very well be possible that restriction of assembly ends up having more weight in the statistical analysis than launching armed attacks against the group if its frequency is higher. In order to make the analysis more accurate, the weights of those events needs to be taken into consideration.

For assigning weights, my starting point was, once again, Krain's (2000) scale of repression and accommodation. Krain's scale is initially based on the rankings of 30 experts in the field. The experts were asked to rank the repressive and accommodative events on a 1 to 5 scale. The average scores for each event were calculated and then rounded to the nearest whole number. To be able to make finer distinctions, Krain took the square of the raw average score and assigned new scores to the events ranging from 1 to 25 (Krain 2000:42-43). So, for example, while arresting opposition leader and armed attack received a score of 3 by the expert rankings, Krain scored them as 7 and 12 respectively. By expanding the range of the weights, Krain gained enough flexibility to rank events which originally fell into the same score category.

As a wider range of scores allows me to rank the events with more precision and thus to see the increases or decreases in the intensity of the actions, I decided to use a range between 1 and 25 as well. I first assigned similar scores to the repressive and accommodative events that Krain had on his list. Then I ranked the events which I had added in the previous step that were not in Krain's list. For example, while arresting opposition leaders is on Krain's original list, I included violent arrests of opposition leaders into my list of repressive events. These additions inevitably led to the modification of several scores. The addition of a violent event to the list meant that it had to have a score more than the non-violent version of it. So, the score was assigned based on other violent events with similar intensity. As a general principle, the violent events were assigned a 4 point higher score than the non-violent versions. ${ }^{28}$ Once this rule was established, similar events were modified based on the same principle. Finally, I made some adjustments to the scale based on case-specific characteristics. Throughout the data collection process, I read thousands of newspaper articles on the same subject, which gave me a good understanding of the actions of the state and the groups. I was, therefore, able to understand how the state used certain types of policies in what kind of context and used this insight to modify the

28 This 4 point difference is enough to account for the difference in intensity, yet does not place the violent and nonviolent versions of the same event at the extreme ends of the scale. 
scale. For example, while declaration of martial law has a score of 10 in Krain's scale, it is 21 in my scale because the Indian state declared martial law in situations where other repressive measures had already been taken and martial law was seen as the only option left to halt the further deterioration of law and order. Therefore, declaration of martial law was assigned a dramatically higher score than violent or non-violent putdown of demonstrations. Even with these various modifications, the correlation coefficient for accommodative and repressive events between the new scale and Krain's scale is relatively strong (.92 and .78 respectively).

I then applied these similar guidelines to assign scores to group actions and external support events. The most severe forms of collective action and external support events were assigned scores closer to 25 and the least severe were assigned scores closer to 1 . Actions included as options under both the state actions or group actions received similar scores. For example, armed attack receives a score of 20 both in the list of state's repressive actions and the group's most threatening actions list. Similarly, negotiating receives the same score of 6 in both the state's and group's conciliatory actions lists.

This systematic and consistent procedure of assigning weights was particularly important in ensuring some degree of balance and objectivity in this otherwise subjective process.

Subjectivity is a legitimate concern both with Krain's scale and also with my scale as, indeed, it is with any other weighting scheme. As there are no objective criteria used to rank such events, any ranking inevitably involves some kind of a judgment call on the researcher's part. However, the application of the same principles across all types of actions will reduce the bias to a minimum and prevent it from affecting the analysis in a significant way. 


\section{CODEBOOK}

\section{EVENT LIST FOR ACCOMMODATION}

\begin{tabular}{|c|c|c|c|}
\hline Main Category & Specific Category & Code & $\begin{array}{c}\text { Adjusted } \\
\text { Weight } \\
(W) \\
\end{array}$ \\
\hline \multirow[t]{5}{*}{ NEGOTIATIONS } & & 110 & \\
\hline & Broad statement of guarantee of rights & 1111 & 4 \\
\hline & Low-level concession & 1112 & 1 \\
\hline & Compromise reached & 1113 & 15 \\
\hline & Negotiations begun & 1114 & 6 \\
\hline \multicolumn{2}{|c|}{ JUDICIAL ACCOMMODATION } & 120 & \\
\hline & $\begin{array}{l}\text { Reduction in fines, taxes, fees, } \\
\text { punishment for compellance }\end{array}$ & 1211 & 4 \\
\hline & Removing restrictive law/regulation & 1212 & 5 \\
\hline & Allowing emigration & 1213 & 7 \\
\hline & Allowing return from exile & 1214 & 8 \\
\hline & $\begin{array}{l}\text { Outlawing repressive apparatus institution, } \\
\text { practice }\end{array}$ & 1215 & 8 \\
\hline & Prosecution of enemies of target group & 1216 & 1 \\
\hline & Stays of execution & 1217 & 5 \\
\hline & Freeing prisoners & 1218 & 10 \\
\hline & General Amnesty & 1220 & 14 \\
\hline & Legalizing Group Membership & 1221 & 12 \\
\hline
\end{tabular}

NON-JUDICIAL ACCOMMODATION

130

\begin{tabular}{lll} 
Organizing discussion meetings, committees & 1311 & 3 \\
\hline Increasing access to information & 1312 & 4 \\
\hline Providing selective incentives & 1313 & 8 \\
\hline Giving positive publicity & 1314 & 4 \\
\hline $\begin{array}{l}\text { Introducing enabling } \\
\text { mechanisms/entitlement }\end{array}$ & 1315 & 6 \\
\hline Increasing opportunities for participation & 1316 & 9 \\
\hline $\begin{array}{l}\text { Small-scale diversion of } \\
\text { resources to group }\end{array}$ & 1317 & 5 \\
\hline Abandoning project hurtful to group & 1318 & 4 \\
\hline Increasing security of target group & 1320 & 1 \\
\hline Increasing access to markets & 1321 & 9 \\
\hline $\begin{array}{l}\text { Large-scale redistribution of } \\
\text { assets/resources }\end{array}$ & 1322 & 10 \\
\hline Direct aid (money, forces) to challenger & 1323 & 12 \\
\hline Withdrawal of Army & 1324 & 16 \\
\hline
\end{tabular}




\begin{tabular}{lll} 
Encouraging/allowing separatism & 1411 & 18 \\
\hline Incorporation into government & 1412 & 25 \\
\hline
\end{tabular}

OTHER

910

EVENT LIST FOR REPRESSION

\begin{tabular}{llll}
\hline \hline \multirow{2}{*}{ Main Category } & Specific Category & Code & $\begin{array}{c}\text { Adjusted } \\
\text { Weight } \\
\text { (W) }\end{array}$ \\
\hline RESTRICT & & 210 \\
\hline \multirow{2}{*}{ Preventive Repression } & $\begin{array}{l}\text { Restricting access to resources, } \\
\text { necessities, jobs }\end{array}$ & 2111 & 6 \\
\cline { 2 - 4 } & Restricting assembly & 2112 & 5 \\
\cline { 2 - 3 } & $\begin{array}{l}\text { Restricting freedom of } \\
\text { communication, speech } \\
\text { and distribution of information }\end{array}$ & & \\
\cline { 2 - 3 } & Restricting emigration, mobility & 2113 & 5 \\
\cline { 2 - 3 } & Prohibitive fines, taxes, fees, regulation & 2114 & 6 \\
\cline { 2 - 3 } & & 2115 & 4 \\
\end{tabular}

SEIZE

220

Preventive Repression

Arrest

\begin{tabular}{lll} 
Seizing assets & 2211 & 7 \\
\hline Arrests/ Detentions & 2212 & 9 \\
\hline Mass Arrests (>25) & 2213 & 14 \\
\hline Non-violent Arrest of Opposition Leaders & 2418 & 10 \\
\hline Violent Arrest of Opposition Leaders & 24199 & 14 \\
\hline
\end{tabular}

WARN

230

\begin{tabular}{|c|c|c|c|}
\hline \multirow[t]{8}{*}{ Preventive Repression } & Public threat of violence/punishment & 2311 & 5 \\
\hline & Show of force & 2312 & 6 \\
\hline & Exemplary punishment/deterrent & 2313 & 9 \\
\hline & Show trials/political trials & 2314 & 8 \\
\hline & Compellance: Punishing non-performance & 2315 & 4 \\
\hline & Expulsion/purge from party or ruling elite & 2316 & 3 \\
\hline & Making groups more visible, easily spotted & 2317 & 4 \\
\hline & Halt Negotiations & 2318 & 6 \\
\hline \multicolumn{2}{|l|}{ JUDICIAL ACTIONS } & 240 & \\
\hline \multirow[t]{5}{*}{ Preventive Repression } & Curfew & 2411 & 10 \\
\hline & Martial law declared & 2412 & 21 \\
\hline & "Special" extra-legal courts set-up & 2413 & 8 \\
\hline & $\begin{array}{l}\text { Suspension of parts of constitution or } \\
\text { the regular workings of government / issuing } \\
\text { ordinance }\end{array}$ & 2414 & 16 \\
\hline & Outlawing organizations, groups, industries & 2415 & 15 \\
\hline
\end{tabular}


Suspending or censoring news media/speech

Ousting groups from government

2417

Exiles/expulsions

Trials in absentia

2420

Forced conscription

2421

President's Rule/Governor's Rule

2422

Religious suppression/persecution

2423

2424

14 15

10

8

8

18

9

NON-JUDICIAL ACTIONS

Reactionary Repression

Non-violent putdown of

demonstration/strikes/hartals

Violent putdown of demonstration/strikes/hartals, lathi-charging and teargassing

Non-violent disruption of group organization

Violent disruption of group organization

Calling in

additional police posts/ secret police/special

forces

250

2511

7

25119

2512

25129

7

11

2514

6

USE OF FORCE

Reactionary Repression

OTHER

\begin{tabular}{lll} 
& 260 & \\
\hline Beating up & 26119 & 11 \\
\hline Clashes with group & 26129 & 14 \\
\hline Use of torture & 26139 & 16 \\
\hline Forced resettlement & 26149 & 18 \\
\hline Armed attack & 26159 & 20 \\
\hline Forced labor & 26169 & 12 \\
\hline $\begin{array}{l}\text { Forced subjugation/integration } \\
\text { of communities }\end{array}$ & \\
\hline Disappearance & 26179 & 9 \\
\hline Damaging property & 26189 & 21 \\
\hline Bombing & 26199 & 14 \\
\hline Burning houses, bridges, etc. & 26209 & 21 \\
\hline Burning entire villages & 26219 & 21 \\
\hline Manufactured famine or draught & 26229 & 25 \\
\hline Mass rape & 26239 & 20 \\
\hline Concentration Camps & 26249 & 21 \\
\hline & 26259 & 18 \\
\hline
\end{tabular}

Note: All actions that involve violence end with 9.

EVENT LIST FOR COLLECTIVE ACTION

\begin{tabular}{|c|c|c|c|}
\hline Main Category & Specific Category & Code & $\begin{array}{l}\text { Weight } \\
\text { (W) }\end{array}$ \\
\hline ACCOMMODATIVE ACTION & & 510 & \\
\hline & $\begin{array}{l}\text { Broad statement of guarantee } \\
\text { of rights and security of government officials }\end{array}$ & 5111 & 4 \\
\hline
\end{tabular}




\begin{tabular}{lcc} 
Low-level concession & 5112 & 1 \\
\hline Compromise reached & 5113 & 15 \\
\hline Negotiations begun & 5114 & 6 \\
\hline Freeing hostages/prisoners & 5115 & 10 \\
\hline $\begin{array}{l}\text { Abandoning plans/actions/strikes/boycotts / } \\
\text { demonstrations etc. hurtful to state }\end{array}$ & 5116 & 4 \\
\hline $\begin{array}{l}\text { Allowing government access to } \\
\text { resources, mines, oil facilities, etc. }\end{array}$ & 5117 & 9 \\
\hline Renouncing secessionist goals & 5118 & 16 \\
\hline Acceptance of an Agreement & 5120 & 18 \\
\hline Termination of Separatist Movement & 5121 & 20 \\
\hline Announcing ceasefire & 5122 & 15 \\
\hline
\end{tabular}

CONTENTIOUS ACTIONS

LOW INTENSITY COLLECTIVE ACTION 520

\begin{tabular}{lll}
$\begin{array}{l}\text { Mild negative statements } \\
\text { about federal government }\end{array}$ & 5211 & 1 \\
\hline $\begin{array}{l}\text { Mild negative statements } \\
\text { about local government }\end{array}$ & 5212 & 1 \\
\hline $\begin{array}{l}\text { Strong negative statements } \\
\text { about federal government }\end{array}$ & 5213 & 3 \\
\hline $\begin{array}{l}\text { Strong negative statements } \\
\text { about local government }\end{array}$ & 5214 & 3 \\
\hline Organizing meetings & 5311 & 6 \\
\hline Distributing information & 5312 & 5 \\
\hline Forming an organization & 5313 & 8 \\
\hline
\end{tabular}

MEDIUM INTENSITY COLLECTIVE ACTION 540

\begin{tabular}{llc} 
Non-violent Strike (hartal) & 5411 & 7 \\
\hline Violent Strike (hartal) & 54119 & 11 \\
\hline Non-Violent Bandh (general strike) & 5412 & 9 \\
\hline $\begin{array}{l}\text { Violent Bandh (general strike) } \\
\text { Non-violent Small-scale demonstrations } \\
\text { (less than 200 participants) }\end{array}$ & 54129 & 11 \\
\hline $\begin{array}{l}\text { Violent Small-scale demonstrations } \\
\text { (less than 200participants) }\end{array}$ & 5413 & 7 \\
\hline $\begin{array}{l}\text { Non-violent Large-scale demonstrations } \\
\text { (more than 200 participants) }\end{array}$ & 54139 & 11 \\
\hline
\end{tabular}

Violent Large-scale demonstrations

\begin{tabular}{llc} 
(more than 200 participants) & 54149 & 11 \\
\hline Non-violent Sit-ins & 5415 & 7 \\
\hline Violent Sit-ins & 54159 & 11 \\
\hline Commercial Boycotts & 5416 & 7 \\
\hline Electoral boycotts & 5417 & 10 \\
\hline Halt negotiations & 5418 & 6 \\
\hline Forming a political wing / party & 5420 & 12 \\
\hline
\end{tabular}




\begin{tabular}{lll} 
Running candidate in the election & 5421 & 12 \\
\hline Threat of violence/agitation & 5422 & 5 \\
\hline Violation of curfew, martial law, etc. & 5423 & 5 \\
\hline
\end{tabular}

Surveillance, links with spies, acquiring information through clandestine means

\begin{tabular}{lll}
\hline Assaults & 55109 & 11 \\
\hline Robbery/stealing-damaging property & 55119 & 14 \\
\hline Clashes & 55129 & 15 \\
\hline Direct confrontation with army or paramilitaries & 55299 & 20 \\
\hline Sabotage & 55139 & 17 \\
\hline Abduct tourists/journalists/citizens & 55149 & 15 \\
\hline Abduct and execute tourists/journalists/citizens & 55249 & 20 \\
\hline Abduct politicians & 55159 & 16 \\
\hline Abduct and execute politicians & 55259 & 20 \\
\hline Seizing buildings & 55169 & 17 \\
\hline Using training camps & 55179 & 16 \\
\hline Securing access to arms & 55189 & 16 \\
\hline Armed attack & 55199 & 20 \\
\hline Bombing & 55209 & 21 \\
\hline Riots & 55219 & 17 \\
\hline Burning houses, bridges, etc. & 55229 & 21 \\
\hline Burning entire villages & 55239 & 25 \\
\hline
\end{tabular}

All actions that involve violence en with 9.

SPLITS

\begin{tabular}{|c|c|c|c|}
\hline Main Category & Specific Category & Code & $\begin{array}{c}\text { Weight } \\
(\mathbf{W})\end{array}$ \\
\hline & Disagreements between factions & 5611 & 5 \\
\hline & Forming an organization as a result of splits & 5612 & 10 \\
\hline & Expelling members & 5614 & 7 \\
\hline & Armed attack against other factions & 56139 & 20 \\
\hline & Militants surrendering & 5615 & 10 \\
\hline
\end{tabular}

EVENT LIST FOR EXTERNAL SUPPORT TO THE STATE

\begin{tabular}{lllc}
\hline \hline Main Category & Specific Category & Code & $\begin{array}{c}\text { Weight } \\
\text { (W) }\end{array}$ \\
\hline MATERIAL SUPPORT & & 810 & \\
\hline LOW & Humanitarian Aid & 8111 & 2 \\
\hline
\end{tabular}




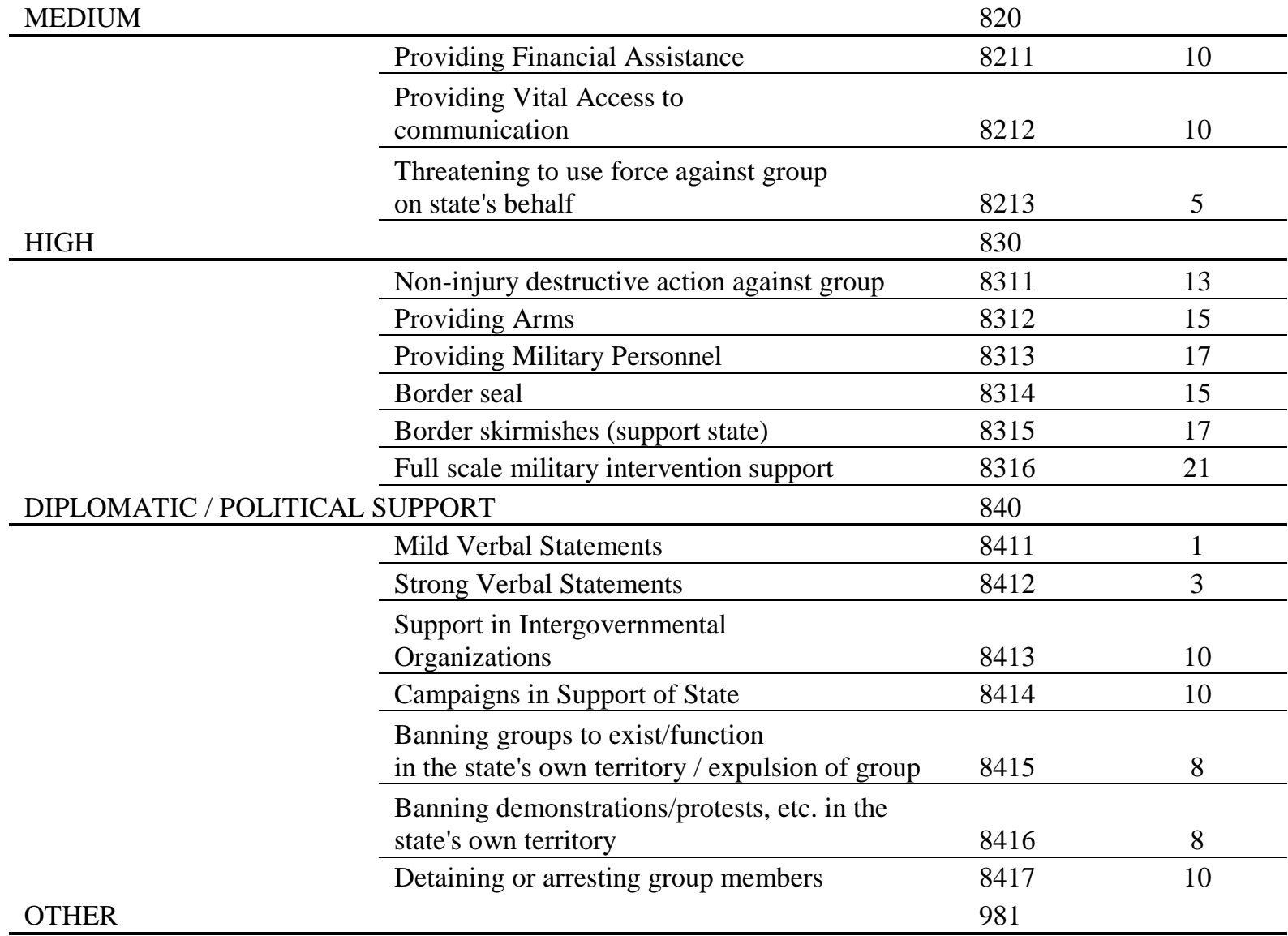

\section{EVENT LIST FOR EXTERNAL SUPPORT TO THE GROUP}

\begin{tabular}{|c|c|c|c|}
\hline Main Category & Specific Category & Code & $\begin{array}{l}\text { Weight } \\
\text { (W) }\end{array}$ \\
\hline TANGIBLE SUPPORT & & 850 & \\
\hline LOW & Humanitarian Aid & 8511 & 2 \\
\hline MODERATE & & 860 & \\
\hline \multirow[b]{6}{*}{$\begin{array}{l}\text { HIGH - PHYSICAL } \\
\text { INVOLVEMENT }\end{array}$} & Providing Sanctuary/training & 8611 & 14 \\
\hline & Providing Base of Operation & 8612 & 14 \\
\hline & Providing Financial Assistance & 8613 & 10 \\
\hline & $\begin{array}{l}\text { Providing Vital Access to } \\
\text { communication }\end{array}$ & 8614 & 10 \\
\hline & $\begin{array}{l}\text { Threatening the state to intervene } \\
\text { on group's behalf }\end{array}$ & 8615 & 5 \\
\hline & & 870 & \\
\hline & Non-injury destructive action against state & 8711 & 13 \\
\hline & Providing Arms & 8712 & 15 \\
\hline
\end{tabular}


Providing Military Personnel under secessionist command

8713

Border closures

8714

Border skirmishes (support group)

8715

Firing Across Borders

8716

Full scale military intervention

8717

17 15

17

16

21

DIPLOMATIC / POLITICAL SUPPORT

880

\begin{tabular}{lcc} 
Mild Verbal Statements & 8811 & 1 \\
\hline Strong Verbal Statements & 8812 & 3 \\
\hline $\begin{array}{l}\text { Support in Intergovernmental } \\
\text { Organizations }\end{array}$ & 8813 & 10 \\
\hline Campaigns in Support of Groups & 8814 & 10 \\
\hline $\begin{array}{l}\text { Allowing groups to exist/function } \\
\text { in the state's own territory }\end{array}$ & 8815 & 8 \\
\hline $\begin{array}{l}\text { Allowing demonstrations/protests, etc. in the } \\
\text { state's own territory }\end{array}$ & 8816 & 8 \\
\hline $\begin{array}{l}\text { Freeing detained/arrested group } \\
\text { members out of prison }\end{array}$ & 8817 & 10 \\
\hline Granting Asylum to leadership of group & 8818 & 14 \\
\hline & & \\
\hline
\end{tabular}

ACTORS /TARGETS FOR ASSAM

STATE

33100

\begin{tabular}{ll} 
Federal Government & 331001 \\
\hline Local Government & 331002 \\
\hline Governor & 331011 \\
\hline Shri L.P. Singh, ICS & 3310111 \\
\hline Shri P. Mehrotra & 3310112 \\
\hline Shri T.S. Misra & 3310113 \\
\hline Shri B. N. Sing & 3310114 \\
\hline Shri Harideo Joshi & 3310115 \\
\hline Shri Justice Anisetti Roghuvir, Chief & \\
Justice, Assam & 3310116 \\
\hline Shri D. D. Thakur & 3310117 \\
\hline Shri Lok Nath Misra & 3310118 \\
\hline Chief Minister & $\mathbf{3 3 1 0 0 3}$ \\
\hline CM Shri Golap Borbora & 3310031 \\
\hline CM Shri Jogenda Nath Hazarika & 3310032 \\
\hline CM Shrimati Anowara Taimur & 3310033 \\
\hline CM Shri Kesab Chandra Gogoi & 3310034 \\
\hline CM Shri Hiteswar Saikia & 3310035 \\
\hline CM Shri Prafulla Kumar Mahanta & 3310036 \\
\hline
\end{tabular}




\begin{tabular}{ll} 
Media & 331101 \\
\hline Students & 331102 \\
\hline Workers & 331103 \\
\hline Peasants & 331104 \\
\hline Educators & 331105 \\
\hline Politicians & 331106 \\
\hline Political Activists & 331107 \\
\hline Elites & 331108 \\
\hline Local Tourists & 331109 \\
\hline Foreign Tourists & 331110 \\
\hline Foreign Journalists & 331111 \\
\hline Foreign Politicians & 331112 \\
\hline Bengali nationals trying to immigrate & 331113 \\
\hline Civil servants & 331114 \\
\hline Nepali nationals trying to immigrate & 331115 \\
\hline Businessmen/traders & 331116 \\
\hline Foreign businessmen/traders & 331117 \\
\hline Other & 33910 \\
\hline
\end{tabular}

POLITICAL PARTIES 33120

\begin{tabular}{|c|c|c|}
\hline \multirow[b]{8}{*}{ RELIGIOUS GROUPS } & Congress Party & 331201 \\
\hline & Janata Party & 331202 \\
\hline & $\mathrm{BJP}$ & 331203 \\
\hline & Asom Gana Parishad (AGP) & 331204 \\
\hline & Asom Gana Parishad (Splinter) & 3312045 \\
\hline & United Minorities Front & 331205 \\
\hline & Other & 33920 \\
\hline & & 33130 \\
\hline & Muslims & 331301 \\
\hline & Hindus & 331302 \\
\hline & Sikhs & 333103 \\
\hline & Buddhists & 331304 \\
\hline & Christian & 331305 \\
\hline & Other & 33930 \\
\hline
\end{tabular}

\begin{tabular}{ll} 
Population & 331401 \\
\hline Assamese & 331402 \\
\hline Bangladeshi immigrants & 331403 \\
\hline Tribals & 331404 \\
\hline Nepalese & 331405 \\
\hline Bodos & 331406 \\
\hline Hindi-speaking people & 331407 \\
\hline Other & 33940 \\
\hline
\end{tabular}


United Liberation Front of Assam

331501

All Assamese Student Union (AASU)

331502

All Assam Gana Sangram Parishad

(AAGSP)

331503

Asom Sahitya Sabha

331504

All Assam Minority Students Union (not insurgent)

331505

Lok Parishad

(AJYCP) - Assam Nationalistic Youth and

Students Forum)

331506

\begin{tabular}{ll}
\hline Other & 331507 \\
\hline
\end{tabular}

STATE ENFORCEMENT

33160

Police

331601

Paramilitary troops

331602

Army

331603

Border Security Force

331604

Other

33960

EXTERNAL ACTORS

33170

US

331701

\begin{tabular}{ll}
\hline United Kingdom & 331701 \\
\hline United Nations & 331702 \\
\hline Regional Organizations & 331703 \\
\hline China & 331704 \\
\hline Bhutan & 331705 \\
\hline Bangladesh & 331706 \\
\hline Nepal & 331707 \\
\hline Burma (Myanmar) & 331708 \\
\hline Pakistan & 331709 \\
\hline Other & 331710 \\
\hline
\end{tabular}




\section{B. DESCRIPTIVE STATISTICS}

TABLE B-1 Descriptive Statistics for the Main Variables (Weighted)

\begin{tabular}{lcccrr} 
Variable & Observation & \multicolumn{1}{l}{ Mean } & $\begin{array}{c}\text { Standard } \\
\text { Deviation }\end{array}$ & Minimum & Maximum \\
\hline Protest Activity & 345 & 45.81 & 131.57 & 0 & 1278 \\
\hline Repression & 345 & 38.95 & 110.18 & 0 & 866 \\
\hline Accommodation & 345 & 5.60 & 13.19 & 0 & 96 \\
\hline Heavy Violence & 345 & 32.56 & 80.22 & 0 & 780 \\
\hline
\end{tabular}




\section{ROBUSTNESS CHECKS}

TABLE C-1 ZINB and PAR Estimates for Number of Protest Activity in Assam (Unweighted Data)

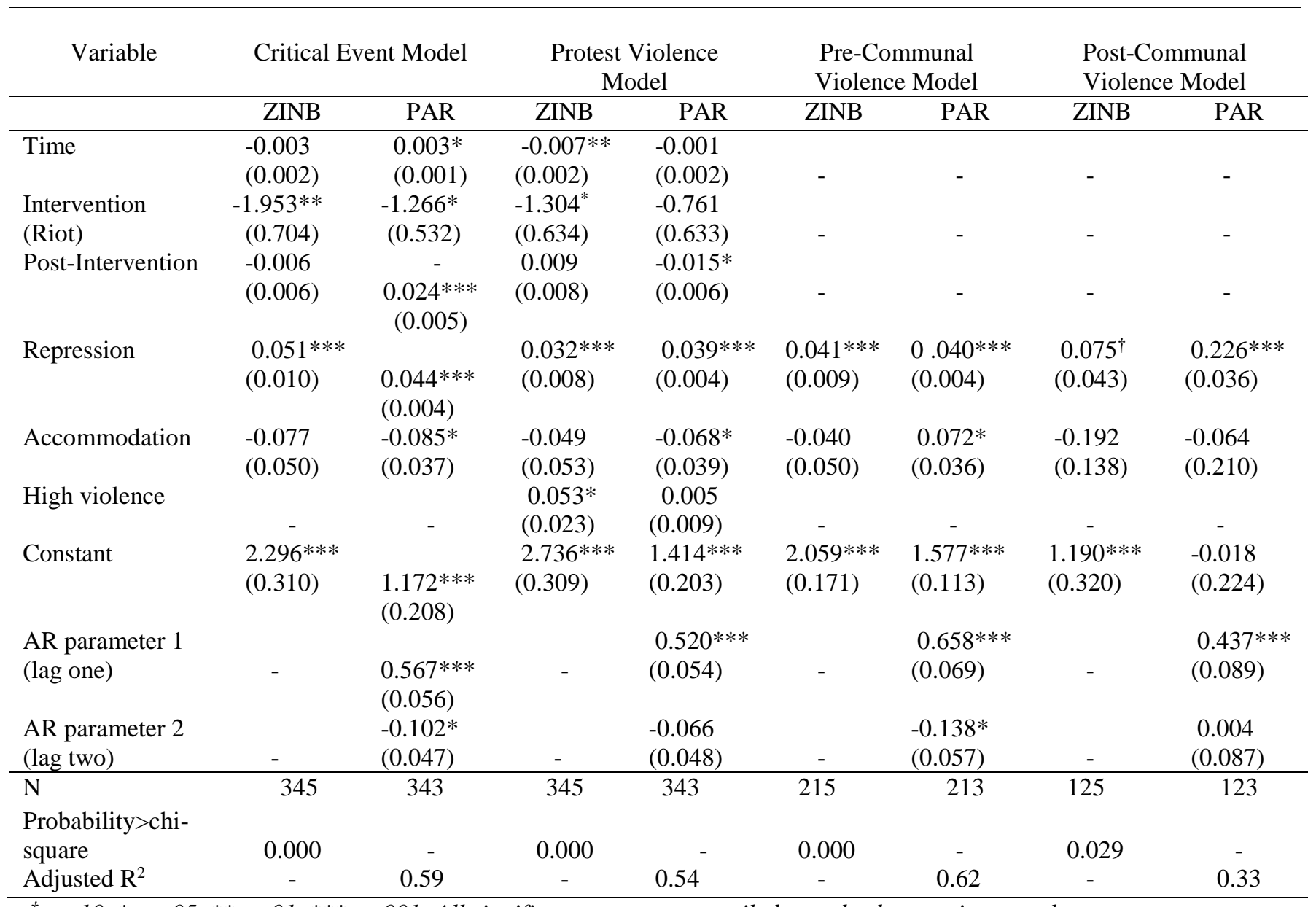

${ }^{\dagger} p<.10, * p<.05, * * p<.01, * * * p<.001 ;$ All significant tests are two-tailed, standard errors in parentheses 
TABLE C-2 ZINB and PAR Estimates for Violent and Nonviolent Protest Activity in Assam

\begin{tabular}{|c|c|c|c|c|}
\hline \multirow[t]{2}{*}{ Variable } & \multicolumn{2}{|c|}{ Nonviolent Protest Activity } & \multicolumn{2}{|c|}{ Violent Protest Activity } \\
\hline & ZINB & PAR & ZINB & PAR \\
\hline Time & $\begin{array}{l}-0.006 * * * \\
(0.002)\end{array}$ & $\begin{array}{l}-0.001 \\
(0.001)\end{array}$ & $\begin{array}{l}0.012 * * \\
(0.004)\end{array}$ & $\begin{array}{l}0.022 * * \\
(0.007)\end{array}$ \\
\hline $\begin{array}{l}\text { Intervention } \\
\text { (Riot) }\end{array}$ & $\begin{array}{l}-1.259^{*} \\
(0.532)\end{array}$ & $\begin{array}{l}-1.788^{*} \\
(0.726)\end{array}$ & $\begin{array}{l}2.743^{*} \\
(1.357)\end{array}$ & $\begin{array}{l}3.215^{* * * *} \\
(0.529)\end{array}$ \\
\hline Post-Intervention & $\begin{array}{l}-0.006 \\
(0.006)\end{array}$ & $\begin{array}{l}-0.014^{*} \\
(0.006)\end{array}$ & $\begin{array}{l}-0.037^{*} \\
(0.018)\end{array}$ & $\begin{array}{l}-0.090^{*} \\
(0.036)\end{array}$ \\
\hline Repression & $\begin{array}{l}0.003^{* * * *} \\
(0.001)\end{array}$ & $\begin{array}{l}0.004 * * * \\
(0.000)\end{array}$ & $\begin{array}{l}0.008 * * \\
(0.003)\end{array}$ & $\begin{array}{l}-0.000 \\
(0.000)\end{array}$ \\
\hline Accommodation & $\begin{array}{l}-0.017^{*} \\
(0.008)\end{array}$ & $\begin{array}{l}-0.025 * * \\
(0.007)\end{array}$ & $\begin{array}{l}-0.047 \\
(0.030)\end{array}$ & $\begin{array}{l}0.030^{*} \\
(0.012)\end{array}$ \\
\hline Constant & $\begin{array}{l}4.887 * * * \\
(0.258)\end{array}$ & $\begin{array}{l}3.580 * * * \\
(0.195)\end{array}$ & $\begin{array}{l}2.611^{* *} \\
(0.797)\end{array}$ & $\begin{array}{r}0.923 \\
(1.389)\end{array}$ \\
\hline $\begin{array}{l}\text { AR parameter } 1 \text { (lag } \\
\text { one) }\end{array}$ & - & $\begin{array}{l}0.492^{* * * *} \\
(0.055)\end{array}$ & - & $\begin{array}{l}0.088^{+} \\
(0.046)\end{array}$ \\
\hline $\begin{array}{l}\text { AR parameter } 2 \text { (lag } \\
\text { two) }\end{array}$ & - & $\begin{array}{l}-0.048 \\
(0.049) \\
\end{array}$ & - & $\begin{array}{r}0.087 \\
(0.059) \\
\end{array}$ \\
\hline $\mathrm{N}$ & 345 & 343 & 345 & 343 \\
\hline Probability>chi-square & 0.000 & - & 0.000 & - \\
\hline Adjusted $\mathrm{R}^{2}$ & - & 0.59 & - & 0.32 \\
\hline
\end{tabular}

${ }^{t} p<.10, * p<.05, * * p<.01, * * * p<.001 ;$ All significant tests are two-tailed, standard errors in parentheses 
TABLE C-3 Critical Event Model and Cooptation Model Estimates of Protest Activity (January 1979 - June 1983)

\begin{tabular}{lcc}
\hline \multicolumn{1}{c}{ Variable } & $\begin{array}{c}\text { Critical Event } \\
\text { Model }\end{array}$ & $\begin{array}{c}\text { Cooptation } \\
\text { Model }\end{array}$ \\
\hline Time & $\begin{array}{c}0.002 \\
(0.002)\end{array}$ & $\begin{array}{c}0.004^{\dagger} \\
(0.002)\end{array}$ \\
\hline Intervention & $-2.777^{* * *}$ & - \\
(Communal Violence) & $(0.733)$ & \\
\hline Post-Intervention & $-0.163^{*}$ & - \\
& $(0.073)$ & \\
\hline \multirow{2}{*}{ Repression } & $0.004^{* * *}$ & - \\
& $(0.001)$ & \\
\hline \multirow{2}{*}{ Accommodation } & -0.016 & 0.004 \\
& $(0.012)$ & $(0.013)$ \\
\hline \multirow{2}{*}{ Constant } & 4.089 & $4.265^{* * *}$ \\
& $(0.350)^{* * *}$ & $(0.381)$ \\
\hline \multirow{2}{*}{ N } & 232 & 232 \\
Probability>chi-square & 0.000 & 0.2083 \\
& & \\
\hline
\end{tabular}

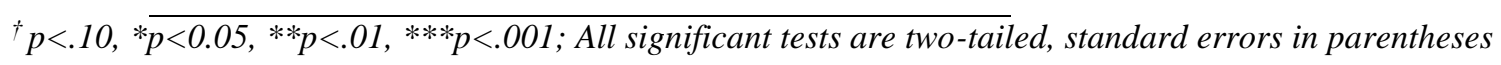


References:

Alimi, Eitan Y. (2009) Mobilizing under the Gun: Theorizing Political Opportunity Structure in a Highly Repressive Setting. Mobilization 14(2):219-37.

Baruah, Sanjib. (1986) Immigration, Ethnic Conflict, and Political Turmoil--Assam, 1979-1985. Asian Survey 26(11):1184-206. . (1999) India against Itself : Assam and the Politics of Nationality. Critical Histories. Philadelphia: University of Pennsylvania Press.

Beissinger, Mark R. (2002) Nationalist Mobilization and the Collapse of the Soviet State. Cambridge: Cambridge University Press.

Bond, Doug, Joe Bond, Churl Oh, J. Craig Jenkins, and Charles Lewis Taylor. (2003) Integrated Data for Events Analysis (Idea): An Event Typology for Automated Events Data Development. Journal of Peace Research 40(6):733-45.

Brandt, Patrick T., and John T. Williams. (2001) A Linear Poisson Autoregressive Model: The Poisson Ar(P) Model. Political Analysis 9(2):164-84.

Brandt, Patrick T., John T. Williams, Benjamin A. Fordham, and Brian Pollins. (2000) Dynamic Modeling for Persistent Event Count Time Series. American Journal of Political Science 44(4):823-43.

Capoccia, Giovanni, and R. Daniel Kelemen. (2007) The Study of Critical Junctures: Theory, Narrative, and Counterfactuals in Historical Institutionalism. World Politics 59(3):34169.

Chenoweth, Erica, and Maria J. Stephan. (2011) Why Civil Resistance Works : The Strategic Logic of Nonviolent Conflict. New York: Columbia University Press.

Collier, Ruth Berins, and David Collier. (2002) Shaping the Political Arena: Critical Junctures, the Labor Movement, and Regime Dynamics in Latin America. Notre Dame, Ind. :: University of Notre Dame Press.

Davenport, Christian, and Will H. Moore. (2012) The Arab Spring, Winter, and Back Again? (Re)Introducing the Dissent-Repression Nexus with a Twist. International Interactions 38(5):704-13.

Day, Joel, Jonathan Pinckney, and Erica Chenoweth. (2015) Collecting Data on Nonviolent Action: Lessons Learnd and Ways Forward. Journal of Peace Research 52(1):129-33.

della Porta, Donatella, and Sidney Tarrow. (1986) Unwanted Children: Political Violence and the Cycle of Protest in Italy: 1966-1973. European Journal of Political Research 14.

DeVotta, Neil. (2004) Blowback: Linguistic Nationalism, Institutional Decay, and Ethnic Conflict in Sri Lanka. Stanford: Stanford University Press.

Dunning, Thad. (2011) Fighting and Voting: Violent Conflict and Electoral Politics. The Journal of Conflict Resolution 55(3):327-39.

Earl, Jennifer, Andrew Martin, John D. McCarthy, and Sarah A. Soule. (2004) The Use of Newspaper Data in the Study of Collective Action. Annual Review of Sociology 3065-80.

Farnum, Nicholas.R., and LaVerne W. Stanton. (1989) Quantitative Forecasting Methods. PWSKent Pub.

Francisco, Ronald A. (1995) The Relationship between Coercion and Protest: An Empirical Evaluation in Three Coercive States. The Journal of Conflict Resolution 39(2):263-82. 
Gandhi, Rajmohan. April 11. 1983, 1983 Assam: Some Questions and Answers. The Indian Express, 5.

George, Alexander L., and Andrew Bennett. (2005) Case Studies and Theory Development in the Social Sciences. Bcsia Studies in International Security. Cambridge, Mass.: MIT Press.

Goertz, Gary, and Paul F. Diehl. (1995) The Initiation and Termination of Enduring Rivalries: The Impact of Political Shocks. American Journal of Political Science 39(1):30-52.

Gupta, Shekhar February 24, 1983 Assam Violence Has No Set Pattern. The Indian Express, 7. Heraclides, Alexis. (1990) Secessionist Minorities and External Involvement. International Organization 44(3):341-78.

Horowitz, Donald L. (2001) The Deadly Ethnic Riot. Berkeley: University of California Press.

Kimura, Makiko. (2013) The Nellie Massacre of 1983: Agency of Rioters. New Delhi: Sage Publications India.

Koopmans, Ruud. (1997) Dynamics of Repression and Mobilization: The German Extreme Right in the 1990s. Mobilization 2(2):149-65.

Krain, Matthew. (2000) Repression and Accommodation in Post-Revolutionary States. 1st ed. New York: St. Martin's Press.

Linden, Ariel, and John L. Adams. (2011) Applying a Propensity Score-Based Weighting Model to Interrupted Time Series Data: Improving Causal Inference in Programme Evaluation. Journal of Evaluation in Clinical Practice 17(6):1231-38.

Lohmann, Susanne. (1994) The Dynamics of Informational Cascades: The Monday Demonstrations in Leipzig, East German, 1989-91. World Politics 47(October):42-101.

Long, Scott. (1997) Regression Models for Categorical and Limited Dependent Variables. Thousand Oaks: Sage Publications.

Mahoney, James. (2001) The Legacies of Liberalism : Path Dependence and Political Regimes in Central America. Baltimore :: Johns Hopkins University Press.

McAdam, Doug. (1983) Tactical Innovation and the Pace of Insurgency. American Sociological Review 48(6):735-54.

McCarthy, John D., Clark McPhail, and Jackie Smith. (1996) Images of Protest: Dimensions of Selection Bias in Media Coverage of Washington Demonstrations, 1982 and 1991. American Sociological Review 61(3):478-99.

Meyer, David S., and Suzanne Staggenborg. (1996) Movements, Countermovements, and the Structure of Political Opportunity. American Journal of Sociology 101(6):1628-60.

Moore, Will H., and Ronny Lindstrom. (1996) The Violent Intranational Conflict Data Project (Vicdp) Codebook. Department of Political Science, University of California - Riverside.

Narayan, Hemendra. February 19, 1985 Show of Strength by Assam Agitation Leaders. Indian Express.

Nepstad, Sharon Erickson. (2011) Nonviolent Revolutions : Civil Resistance in the Late 20th Century. New York: Oxford University Press.

Piven, Frances Fox, and Richard A. Cloward. (1977) Poor People's Movements: Why They Suceed, How They Fail. New York: Pantheon Books.

Polanyi, Karl. (1957) The Great Tansformation. New York :: Rinehart.

Rasler, Karen. (1996) Concessions, Repression, and Political Protest in the Iranian Revolution. American Sociological Review 61(1):132-52.

Rasler, Karen A., William R. Thompson, and Sumit Ganguly. (2013) How Rivalries End. 1st ed. ed. Philadelphia :: University of Pennsylvania Press. 
Schock, Kurt. (2013) The Practice and Study of Civil Resistance. Journal of Peace Research 50(3):277-90.

. (2005) Unarmed Insurrections : People Power Movements in Nondemocracies. Minneapolis, MN: University of Minnesota Press.

Sharp, Gene. (1973) The Politics of Nonviolent Action. Boston, MA.: Porter Sargent.

Shawki, Noha. (2012) The 2008 Food Crisis as a Critical Event for the Food Sovereignty and Food Justice Movements. International Journal of Sociology of Agriculture and Food 19(3):423-44.

Staggenborg, Suzanne. (1993) Critical Events and the Mobilization of the Pro-Choice Movement. Research in Political Sociology 6319-45.

Svensson, Isak, and Mathilda Lindgren. (2011) From Bombs to Banners? The Decline of Wars and the Rise of Unarmed Uprisings in East Asia. Security Dialogue 43(2):219-37.

Tarrow, Sidney G. (1989) Democracy and Disorder : Protest and Politics in Italy, 1965-1975. Oxford: Oxford University Press. . (1998) Power in Movement : Social Movements and Contentious Politics. Cambridge Studies in Comparative Politics. 2nd ed. Cambridge, U.K. ; New York: Cambridge University Press.

Tilly, Charles. (1978) From Mobilization to Revolution. Reading, Mass.: Addison-Wesley Pub. Co.

Tilly, Charles, and Sidney G. Tarrow. (2007) Contentious Politics. Boulder, Colorado: Paradigm Publishers.

Varshney, Ashutosh. (2002) Ethnic Conflict and Civic Life : Hindus and Muslims in India. New Haven [Conn.]: Yale University Press. 